\title{
El estándar normativo de la injuria laboral*
}

\author{
Pedro Irureta Uriarte**
}

\begin{abstract}
RESUMEN
La legislación laboral chilena ha regulado desde sus orígenes un conjunto de causas de extinción del contrato de trabajo, entre las cuales se encuentran los actos de injuria ejecutados por el trabajador. Esta causal legal permaneció sin mayores modificaciones durante gran parte del siglo $X X$, relegando a la labor jurisprudencial la delimitación de los contornos de esta figura en el ámbito del despido disciplinario. A partir de la Ley $N^{\circ} 19.759$ (2001), el legislador circunscribió la causal a las injurias proferidas por el trabajador al empleador, modificando de esta manera los alcances de la infracción. A pesar del largo tiempo de existencia de esta figura, lo cierto es que la injuria como causa del despido disciplinario no ba sido motivo de especial debate doctrinario, dejando abiertas una serie de interrogantes sobre el verdadero alcance de la causal.
\end{abstract}

Despido - injuria - libertad de expresión

\section{The legal standard ok work slander}

\begin{abstract}
The Chilean work legislation has regulated since its origins a set of causes of dismissal, including slanderous acts committed by workers. This legal causation remained almost unmodified during $20^{\text {th }}$ Century, and the country jurisprudence was in charge of delimitating the outline of this figure in the field of the disciplinary dismissal. As of 2001, with the Act $N^{\circ} 19.759$, legislators circumscribed this causation to slanders uttered by a worker against his/her employer, modifying so the extent of the infraction. In spite of this figure exists since long time ago, slander as causation of disciplinary dismissal bas not been subject of a particular doctrinal debate, leaving an array of questions open on the true extent of this causation.
\end{abstract}

Dismissal - slander - freedom of expression

* Abreviaturas: AL (Actualidad Laboral); BDT (Boletín de la Dirección del Trabajo); CCOM (Código de Comercio); CPR (Constitución Política de la República); CT (Código del Trabajo); GJ (Gaceta Jurídica); RDJ (Revista de Derecho y Jurisprudencia y Gaceta de los Tribunales); RFM (Revista Fallos del Mes); RL (Relaciones Laborales); RPS (Revista de Política Social); TL (Temas Laborales); TS (Tribuna Social).

** Abogado, Doctor en Derecho, Profesor de Derecho del Trabajo de la Universidad Alberto Hurtado, Santiago de Chile. Correo electrónico: piruret@uahurtado.cl

Artículo recibido el 30 de agosto de 2012 y aceptado para su publicación por el Comité Editorial el 26 de octubre de 2012. 


\section{INTRODUCCIÓN}

$\mathrm{E}$ 1 Código del Trabajo sanciona, en su artículo $160 \mathrm{~N}^{\circ} 1$, las denominadas injurias laborales como un supuesto de extinción justificada del contrato. Así lo estipula expresamente la letra d) de dicho artículo al disponer que "El contrato de trabajo termina sin derecho a indemnización alguna cuando el empleador le ponga término invocando una o más de las siguientes causales: 1. Alguna de las conductas indebidas de carácter grave, debidamente comprobadas, que a continuación se señalan: (...) d) Injurias proferidas por el trabajador al empleador".

La norma antes mencionada ya figuraba en las primeras leyes sociales como un supuesto de extinción justificada del contrato de los obreros y de los empleados. Su incorporación en los textos legales se efectuó conjuntamente con otras figuras como la falta de probidad, las vías de hecho o la conducta inmoral grave, como si todas ellas formaran parte de un solo y monolítico catálogo de causas altamente vinculadas a la buena fe contractual ${ }^{1}$. En dicha condición, y durante el siglo XX, la regulación de la injuria permaneció inalterada en los textos laborales sobreviviendo a múltiples reformas legales. Durante la mayor parte de su existencia esta causal de despido no fue motivo de reflexión doctrinaria y los alcances jurídicos de la causal fueron entregados a la resolución casuística de la jurisprudencia. Esta labor jurisprudencial separó claramente la figura penal de la propiamente laboral, exigió la concurrencia de un específico animus injuriandi, y rodeó la calificación de la injuria de una serie de atenuantes o agravantes que permitían resolver los casos puntuales y complejos de extinción contractual.

A partir del año 2001, la Ley N 19.759 modificó la estructura de las causas de despido disciplinario en las cuales se encontraba incrustada la injuria. Por una parte, exigió que todas las hipótesis del artículo $160 \mathrm{~N}^{\circ} 1 \mathrm{CT}$ estuviesen rodeadas de tres elementos básicos en su configuración: la antijuridicidad (en el sentido de que se trataba de figuras indebidas y no justificadas), la necesaria exigencia de comprobación y que la causa presentara una entidad tal que de la misma pudiese concluirse indefectiblemente la gravedad del acto.

${ }^{1}$ El artículo $5^{\circ} \mathrm{N}^{\circ} 6$ de la Ley $\mathrm{N}^{\circ} 4.053$ (de 29 de septiembre de 1924), referida a los obreros, indicó que el contrato de trabajo terminaba por "falta de probidad; vías de hecho; injuria, grave o conducta inmoral". La norma se mantuvo prácticamente igual en el artículo $9^{\circ} \mathrm{N}^{\circ} 6$ del Código del Trabajo de 1931, aun cuando el calificativo de "grave" (que la Ley No 4.053 había incrustado después de la palabra "injuria”), ahora se colocó a continuación de la expresión "conducta inmoral”. Por su parte, el artículo 29 de la Ley N 4.059 , sobre contrato de trabajo de empleados particulares, señalaba que el "contrato de trabajo a que se refiere esta ley, termina por las causales generales de expiración y, en especial, por las señaladas en el artículo 333 del Código de Comercio”. Y resulta que dicho artículo 333 No 3 CCOM estipulaba expresamente que solo eran causas legales de rescisión por parte del principal: las "injurias o actos que, a juicio del Juzgado de Comercio, comprometan la seguridad personal, el honor o los intereses del comitente". En el caso de los empleados, el Código del Trabajo de 1931 modificó de manera más significativa la causal, eliminando la referencia al Código de Comercio e indicando que eran "causales de caducidad del contrato: (...) Las injurias, maltrato, o actos de una de las partes que comprometan la seguridad personal, el honor o los intereses de la otra" (art. $164 \mathrm{~N}^{\circ}$ 8). Sobre el particular, Vid. Tapia Carvajal, J., Legislación del Trabajo en Chile. Algunos antecedentes históricos. Memoria de Prueba, Universidad de Chile, Santiago 1937, pp. 145 y ss; y Rocha Mora, F., La ley de empleados particulares. Imprenta E. Aracena e Hijo, Santiago 1928, p. 51. 
Adicionalmente, la Ley $\mathrm{N}^{\circ} 19.759$ modificó el planteamiento de la injuria. Desde una regulación amplia y genérica se pasó a una redacción más precisa en la cual el sujeto pasivo de la infracción se centraba exclusivamente en el empleador. Además, y recurriendo a palabras muy similares a las que utiliza el artículo 416 del Código Penal, se especificó que el autor de la infracción solo era el trabajador. Estas modificaciones eran congruentes con otros ámbitos de la Ley $\mathrm{N}^{\circ} 19.759$, que buscaban incorporar los criterios propios de la ciudadanía laboral en la esfera regulatoria del contrato de trabajo.

En el presente artículo se pretenden resolver las principales dificultades que presenta la injuria como causal de despido disciplinario, aclarando quiénes son los sujetos involucrados, cuál es su exacta naturaleza laboral y qué respuestas ha dado la jurisprudencia a las situaciones particulares.

\section{Antecedentes}

\section{La evolución regulatoria de la causal}

La incorporación de la injuria, como causa justificada de extinción del contrato, ya se encontraba en el Código del Trabajo de 1931. Siguiendo una tendencia similar a la existente en otros ordenamientos hispanoamericanos (v. gr., Brasil, México y España) ${ }^{2}$, la legislación chilena permitió el despido del trabajador por la mera circunstancia de proferir injurias. Se trataba de una norma abierta, sin mayores especificaciones, aplicable a cualquiera de las partes, y que nunca fue motivo de especial debate doctrinario. De allí la relevancia que adquiría la jurisprudencia en la especificación de los contornos de la causal.

Esta regulación de la injuria se mantuvo intacta en las distintas legislaciones que regularon el despido disciplinario, con posterioridad al Código de $1931^{3}$. Más aún, reformas tan profundas como la Ley $\mathrm{N}^{\circ} 16.455$ (1966) o el Decreto Ley $\mathrm{N}^{\circ} 2.200$ (1978) no modificaron el planteamiento de la causal limitándose a repetir la fórmula legal de las primeras leyes sociales. Sin embargo, a partir de la Ley $\mathrm{N}^{\circ} 19.759$, de 2001, se introdujo un cambio relevante en el planteamiento de la causal primera del artículo $160 \mathrm{CT}$, cuestión que evidentemente obligó a reformular la hipótesis extintiva en lo que respecta a la injuria. En efecto, y dejando de lado la simple invocación genérica, el legislador del año 2001 aclaró que las injurias que se sancionaban eran aquellas "proferidas por el trabajador al empleador" ${ }^{4}$.

${ }^{2}$ Cfr. artículo 482, letras j) y k), de la Consolidación de las Leyes de Trabajo de Brasil; el artículo 47 de la Federal del Trabajo de México (fracciones II, III y IV); y el artículo 54.2 c), del Estatuto de los Trabajadores español.

${ }^{3}$ Cfr. Walker Errázuriz, F., Derecho de las Relaciones Laborales, Editorial Universitaria, $1^{\text {a }}$ edición, Santiago 2003, p. 403.

${ }^{4}$ Si bien la Ley $\mathrm{N}^{\circ} 19.759$ tuvo su origen en un Mensaje del Poder Ejecutivo, lo cierto es que la modificación del artículo $160 \mathrm{~N}^{\circ} 1 \mathrm{CT}$ se debió precisamente a una indicación parlamentaria de los senadores Lavandero, Ruiz De Giorgio y Ruiz-Esquide. 
La modificación antedicha pretendía vincular, de manera más directa, la acción prohibida con la actividad propia del trabajador en la empresa. De esta forma, y congruente con otras reformas introducidas por la Ley $\mathrm{N}^{\circ} 19.759$ con relación a la ciudadanía laboral, se buscaba excluir como fundamento de la causal actos injuriosos de carácter extralaboral o bien que no tuviesen como destinatario a la contraparte del contrato de trabajo. Ciertamente, una regulación muy amplia de esta hipótesis extintiva podía distorsionar el alcance de esta figura y provocar incidencias entre aspectos laborales y meramente privados.

Según se dejó constancia en la discusión parlamentaria, el único objetivo del cambio propuesto "era hacer hincapié en que todas estas conductas (incluida la injuria) deben relacionarse con la actividad de la empresa, puesto que la ley actual no lo deja claramente de manifiesto", corriéndose el riesgo que algún empleador pudiera intentar acciones contra un trabajador por actos realizados fuera del ámbito de la empresa. Atendido lo anterior, la Comisión respectiva (y también la Sala) aprobó unánimemente la modificación ${ }^{5}$. Con todo, la propuesta inicial de los parlamentarios era más extensa que la redacción actual, ya que se buscaba incorporar dentro de los sujetos afectados a los compañeros de labores. Para estos efectos, los senadores propugnaron una redacción más amplia que la que finalmente fue aprobada, centrando el acto injurioso en el contexto de la empresa en la cual se desempeñaba el trabajador: "Injurias proferidas por el trabajador al empleador o a otro trabajador que se desempeñe en la misma empresa”.

No obstante, y encontrándose el proyecto en la Cámara de Diputados, el Poder Ejecutivo presentó una indicación (que era coincidente con otra indicación parlamentaria) para eliminar la frase propuesta en el Senado: "o a otro trabajador que se desempeñe en la misma empresa”. Esta modificación fue aprobada posteriormente, tanto en la Cámara como en el Senado, circunscribiéndose finalmente el ilícito a la fórmula planteada en la Cámara ${ }^{6}$. Por tanto, la configuración de la injuria quedó centrada exclusivamente a las acciones "proferidas por el trabajador al empleador".

${ }^{5}$ Vid. el Informe de la Comisión de Trabajo del Senado en Biblioteca del Congreso Nacional, Historia de la Ley $N^{\circ} 19.759$ Modifica el Código del Trabajo en lo relativo a las nuevas modalidades de contratación, al derecho de sindicación, a los derechos fundamentales del trabajador y a otras materias que indica, p. 312.

${ }^{6}$ A raíz de esta propuesta, en la tramitación parlamentaria se enfrentaron dos posturas. La primera, sustentada por el diputado Paya, que estimaba discriminatorio eliminar la referencia a los compañeros de trabajo como sujetos pasivos de la infracción: "Señor Presidente, lo que aquí se plantea es muy insólito, porque el resultado puede ser que la ley en nuestro país establezca que pegarle al jefe o al dueño de una empresa es sancionable, pero que no lo es si se golpea a un compañero de trabajo. Es decir, se establece que recurrir a vías de hecho con un compañero de trabajo o con un superior, no necesariamente el dueño, no tendrá sanción, lo cual me parece una discriminación muy insólita, y no veo desde qué perspectiva se puede entender como una medida para proteger a los trabajadores". Una posición contraria sostuvo el diputado Aguiló: "De hecho, la letra c) del numeral 22 señala injurias proferidas por el trabajador al empleador. Sin embargo, la indicación agrega, además, injurias proferidas por un trabajador a otro que se desempeñe en la misma empresa, lo cual puede ocurrir dentro o fuera de ella. En ese sentido, podemos imaginar, a modo de ejemplo, a dos trabajadores que en una celebración tienen una discusión o un intercambio de palabras, situación de la que se entera el empleador. Como siempre se están buscando razones para echar a los trabajadores, dicho empleador puede valerse de esa discusión, a lo mejor con palabras subidas de tono, como causal para echar a los trabajadores 


\section{El bien jurídico protegido}

Desde antiguo, la admisión de despidos fundados en injurias del trabajador se ha sustentado en el incumplimiento de los deberes mínimos de convivencia y en las exigencias propias de la disciplina laboral ${ }^{7}$. Tanto en el Código de 1931 como en los textos legales posteriores, la tesis de que el trabajador debía respetar tanto al empleador como a los demás compañeros de trabajo se arraigaba en la idea de que la disciplina interna suponía un requisito indispensable en la estructura organizacional, razón por la cual un atentado a la misma implicaba quebrantar gravemente las obligaciones exigidas al trabajador. A estos criterios se fueron sumando otros elementos, de distinta naturaleza y fundados en una múltiple casuística. Por ejemplo, se argumentaba que los actos injuriosos afectaban la buena fe contractual, la armonía que debe existir en el ambiente de trabajo o eventualmente el contenido ético del contrato y los deberes de obediencia del trabajador.

Los criterios antes expuestos fueron paulatinamente depurándose en la protección de al menos dos aspectos: la armonía necesaria en relaciones de trabajo que se encuentran fundadas en la convivencia periódica y la protección de la disciplina laboral. En efecto, si el contrato de trabajo presupone un contacto personal y cercano entre personas, lógico resulta exigirle a los contratantes un nivel mínimo de comportamiento que asegure el cumplimiento de los fines contractuales. Sin ese mínimo respeto mutuo y recíproco, resulta imposible asegurar el cumplimiento regular de las obligaciones que impone el contrato $^{8}$.

En este orden de ideas, y si efectivamente lo que se busca es asegurar niveles mínimos de disciplina y armonía, entonces las exigencias tendientes a evitar la ejecución de actos injuriosos resulta predicable tanto del trabajador como del empleador. Si el afectado con la injuria resulta ser un compañero de labores, entonces la invocación del fundamento pone énfasis en las exigencias de convivencia normal en el trabajo9; por el contrario, si el sujeto pasivo es el empleador entonces los fundamentos vinculados a la disciplina jerárquica laboral adquieren mayor relevancia, pues se parte de la base que en toda organización se requiere un respeto mínimo hacia aquel que ostenta las facultades

\footnotetext{
de la empresa sin indemnización alguna. Por lo tanto, lo que decimos es que las eventuales injurias entre trabajadores pueden ser motivo de otro tipo de querellas, pero no pueden constituir causales de despido". Vid. la discusión parlamentaria en "Historia", cit., p. 1099.

7 Para una sistematización de los fundamentos de esta causal de despido, Vid. García Ninet, J. I., "Ofensas verbales o físicas al empresario o a otras personas del entorno empresarial", en Estudios sobre el despido disciplinario, Acarl, Madrid 1992, pp. 168 y ss.

${ }^{8}$ Vid. sentencia de la Corte Suprema de 28 de enero de 2009 (Causa Ingreso Corte N $^{\circ}$ 7698-2008): "Que, sin duda, la voz injurias debe entenderse en el contexto de la relación laboral que unía a las partes (...) dentro del cual ha de incluirse el respeto mutuo conforme al cual debe desarrollarse un contrato de trabajo, cuya celebración conduce al intercambio del resultado del trabajo y la remuneración".

${ }^{9}$ Cfr. Goñi Sein, J. L., "Las ofensas al honor y la repercusión disciplinaria de las proferidas fuera de la empresa”, en RL T. II (1987), p. 465.
} 
de dirección y ordenación ${ }^{10}$. Con todo, habrá que reconocer que dentro de los fundamentos generales se alza como telón de fondo la protección del honor del afectado, pues se parte de la base que el acto injurioso perjudica injustificadamente la propia imagen, la reputación y la autoestima del sujeto pasivo de la infracción.

\section{Contenido de LA CAUSAL}

\section{El sujeto activo y pasivo de la infracción}

El Código del Trabajo, en una redacción algo incompleta, prefigura la causal de despido como un acto propio del trabajador en contra del empleador. Dicha redacción puede generar la tesis de que el único acto repudiable es aquel que ejecuta directamente el trabajador, o bien pretender que el único afectado pueda ser el empleador. Ambas hipótesis no parecen encuadrarse, al menos históricamente, dentro de los objetivos buscados por la regulación de esta causal.

\subsection{El sujeto pasivo de la infracción}

En primer término, no cabe duda de que el principal afectado con un acto injurioso será el empleador, persona natural o bien su representante. Así lo estipula el artículo 160 $\mathrm{N}^{\mathrm{o}}$ 1, letra d) CT, y obviamente en su caso a las exigencias de disciplina se agregan los deberes de respeto al principio de autoridad necesario para el correcto funcionamiento de la empresa. Ciertamente, la injuria también resulta sancionable cuando esta va dirigida en contra del representante del empleador ya que este ostenta el ejercicio del poder de dirección y, en tal condición, obliga a los mismos deberes de respeto exigidos como si se tratara del propio titular ${ }^{11}$. Incluso más, en un criterio claramente expansivo la jurisprudencia ha hecho aplicable la causal a los casos en que la injuria se dirige en contra del socio principal de la sociedad empleadora (como si se tratara de una misma figura) ${ }^{12}$.

${ }^{10}$ Cfr. entre otros Baylos Grau, A., "Algunas constantes jurisprudenciales sobre los malos tratos y las faltas graves de respeto como causa de despido”. RPS No 116 (1977), pp. 355 y 356; Gárate Castro, J., "Algunos criterios jurisprudenciales sobre malos tratos a considerar en la aplicación del artículo 52 número 2 , c) del Estatuto de los Trabajadores”. RPS N 128 (1980), pp. 186 y 187; y Rojas Rivero, G. P., La libertad de expresión del trabajador, Tecnos, Madrid 1991, p. 78. En igual sentido, sentencia de la Corte del Trabajo de Santiago de 9 de abril de 1980. RDJ, T. LXXVII, sección tercera, (1980), p. 54: “(...) no siendo aceptable que un subalterno emplee vocablos reñidos con la decencia en una conversación o discusión con uno de sus superiores, lo que atenta no solo contra normas mínimas de urbanidad, sino contra la disciplina y orden jerárquico que debe mantenerse en todo establecimiento laboral".

${ }^{11}$ Cfr. en esta línea la sentencia de la Corte Suprema de 9 de marzo de 1999. RDJ, T. XCVI sección tercera (1999), p. 36. En dicha causa se calificó como justificado el despido en razón de los insultos proferidos por un jugador en contra del entrenador del equipo. Por el contrario, las injurias proferidas en contra de un representante del empleador fallecido tienden a excluirse de la hipótesis legal.

${ }^{12}$ Vid. por ejemplo sentencia de la Corte Suprema de 3 de abril de 1997. RDJ, T. XCIV sección tercera (1997), p. 35. Un criterio distinto puede observarse en la sentencia de la Corte Suprema de 20 de marzo de

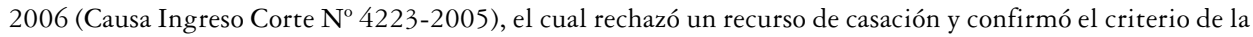


En términos similares, la persona jurídica que actúa como empleador también ha sido considerada como sujeto pasivo de la injuria ${ }^{13}$. En estos casos, y confundiéndose a la persona del empleador con la idea genérica de organización empresarial, se tiende a aceptar que el acto injurioso provoca descrédito y un menoscabo en la integridad del patrimonio moral de la misma. Ello ocurriría, por ejemplo, cuando se ataca el prestigio o reputación comercial de la empresa en cuestiones esenciales de su giro o cuando se realizan denuncias falsas ${ }^{14}$. El tema no es completamente pacífico, ya que identificar el prestigio de la empresa en función de las conductas de sus trabajadores "supondría dejar abierta la puerta a la absoluta discrecionalidad del empresario, en orden a valorar convenientes o no las conductas extralaborales de los trabajadores" ${ }^{15}$. De allí que la imagen,

sentencia de segunda instancia. En dicha causa, los tribunales de instancia concluyeron que las injurias proferidas en una querella invocada, afectaron únicamente al presidente de la Corporación empleadora; "a contrario sensu, no pueden alegarse por la empleadora misma, persona jurídicamente distinta de su representante”.

${ }^{13}$ Cfr. Goñi Sein, "Las ofensas", cit., p. 468. Aunque existe discusión doctrinaria (Vid. por todos Etcheberry, Alfredo, Derecho Penal. Editora Nacional Gabriela Mistral, Santiago 1976, p. 111), la realización de actos injuriosos en contra de personas jurídicas tiende a no ser sancionada penalmente (cuestión que no excluye su punición en otros órdenes normativos). Así lo ha ratificado la sentencia de la Corte Suprema de 4 de junio de 2008 (Causa Ingreso Corte N ${ }^{\circ}$ 1736-2008), la cual parte de la base que "todas las disposiciones que se refieren a la calumnia y la injuria -que corresponden a dos figuras diferentes, pero donde ambas protegen un mismo bien jurídico-, es demostrativa también de que solo pueden tener por sujeto pasivo a un ser humano”. Y agrega: "DECIMOCUARTO: Que, lo que aquí se viene diciendo no obsta ni modifica la circunstancia que en otras ramas del derecho (...) se otorgue debida protección a la reputación, el prestigio o la fama comercial de las personas jurídicas, al punto que en el derecho comercial, por ejemplo, resulta posible accionar y exigir indemnización por los daños que puedan experimentar con motivo de acciones de terceros que vayan en desmedro de esos bienes jurídicos. Y es así, porque para cualquier empresa es relevante contar con un nombre y con una reputación que sea señal de confianza y seguridad para su clientela y esa es precisamente la razón por la cual las personas jurídicas tienen prestigio o reputación, que es una variante de la honra objetiva, como tal, objeto de amparo constitucional. (...). DECIMOSEXTO: Que por las razones señaladas, aun cuando pueda concluirse que efectivamente la norma del artículo $19 \mathrm{~N}^{\circ} 4$ de la Constitución Política de la República garantiza también a las personas jurídicas su derecho a la reputación o prestigio, como facetas objetivas de la honra, es lo cierto que tal derecho no se encuentra protegido penalmente a su respecto. Cobra aplicación en esta parte también, la garantía contenida en el numeral tercero del artículo 19 de la Constitución Política, que en su inciso octavo establece que ninguna ley podrá establecer penas sin que la conducta que se sanciona esté expresamente descrita en ella. Ello significa que las injurias leves no pueden ser cometidas contra una empresa comercial (...)”.

${ }^{14}$ Cfr. García Ninet, cit., p. 180. Vid. en esta línea sentencia de la Corte Suprema de 26 de mayo de 2005. RFM N 533 (2005-2006), p. 1148, la cual destaca el deber que pesa sobre un trabajador en orden a resguardar los intereses de su empleador, "así como su buena imagen y prestigio ante los subcontratistas y demás personas y entidades con la que se relaciona en el ámbito de sus actividades (considerando séptimo)”.

${ }^{15}$ Vid. Ciscart Bea, Neus, El despido por embriaguez y toxicomanía, Bosch, $1^{\text {a }}$ edición, Barcelona 1998, p. 49. De todas formas, en este tipo de materia se parte de la base de que todo comportamiento extralaboral del trabajador resulta irrelevante en la imagen de la organización empresarial, "salvo en hipótesis muy restringidas en las que la naturaleza de la actividad realizada por la empresa fuera incompatible con el comportamiento privado de sus trabajadores". Sobre el particular, Vid. Goñi Sein, José Luis, El respeto a la esfera privada del trabajador, Civitas, $1^{\text {a }}$ edición, Madrid 1988, p. 272. Vid., también, Baylos Grau, "Algunas constantes", cit., p. 262). 
buen nombre o prestigio de la empresa solo podrían alegarse en casos muy calificados y con criterios objetivos para su determinación ${ }^{16}$.

Adicionalmente, tanto doctrina (sobre todo la comparada) como jurisprudencia han venido admitiendo también como sujeto pasivo de la injuria a los compañeros de trabajo y a otras personas que se relacionan con la actividad de la empresa ${ }^{17}$. Así lo indicaron algunos comentaristas del Código de 1931, criterio que con el tiempo fue refrendado por la jurisprudencia ${ }^{18}$.

Más allá de la específica redacción legal, lo cierto es que la injuria proferida a compañeros de labores, ya sea que se encuentren en superior o inferior jerarquía dentro de la organización ${ }^{19}$, ha sido admitida tradicionalmente dentro de las alternativas de infracción en contra de los sujetos pasivos de la conducta prohibida. Aquí se parte de la base de que este tipo de acciones afectan igualmente el indispensable orden y respeto mutuo que se exige en la ejecución del contrato. Es por ello que, hasta antes de la reforma introducida por la Ley $\mathrm{N}^{\circ} 19.759$, jurisprudencia y doctrina aceptaban ampliamente que la causal se aplicara cuando las expresiones se dirigían en contra de un tercero o de un compañero de labores: "Se configura la causal del $\mathrm{N}^{\circ} 1$ del artículo 160 aun cuando el afectado sea un tercero, sin que sea menester que exista perjuicio del empleador y que el comportamiento reprochable del trabajador afecte solo a las relaciones laborales con su empleador" ${ }^{20}$. Este criterio amplio incorporaba también, dentro de los sujetos pasivos

${ }^{16}$ Vid., en esta línea, la postura de Rojas Rivero, "La libertad”, cit., pp. 110 y 111: "La defensa de los bienes de la personalidad no puede sustentarse sobre la base de un interés económico. El derecho al honor (...) no atiende en su configuración a la defensa de intereses patrimoniales. Si a esto se une la consideración del honor como emanación de la dignidad y del libre desarrollo de la personalidad no queda más remedio que negar la existencia de un derecho al honor de las empresa".

${ }^{17}$ Cfr. sentencia de la Corte de Apelaciones de Santiago de 8 de enero de 1988. RDJ, T. LXXXV, sección tercera, (1988), p. 34: "La conducta conflictiva y frecuentemente ofensiva del trabajador respecto del personal de la empresa constituye la causal de caducidad del contrato de trabajo consistente en injurias (...)”. En el plano doctrinal Vid. por todos Gárate Castro, cit., pp. 193 y 194.

18 Vid. Escribar Mandiola, H., Tratado de Derecho del Trabajo. Zig-Zag, Santiago 1944, p. 374: "La jurisprudencia ha establecido que no es forzoso que las 'vías de hecho' e 'injurias' ocurran entre las partes contratantes, ni dentro del establecimiento ni en horas de trabajo".

19 Cfr. por todos Saavedra Acevedo, J., "Los malos tratos y faltas de respeto como causa justa de despido", en Dieciséis lecciones sobre causas de despido, Sección de Publicaciones e Intercambio Facultad de Derecho Universidad de Madrid, Madrid 1969, p. 101.

${ }^{20}$ Sentencia de la Corte Suprema de 25 de junio de 1992. RDJ, T. LXXXIX, sección tercera, 1992, p. 67. Coincidentemente, Vid. la sentencia de la Corte del Trabajo de Santiago de 9 de abril de 1980. RDJ, T. LXXVII, sección tercera (1980), p. 54: “(...) el hecho de ser un simple compañero de trabajo de este, no lo autoriza (al actor) para insultarlo. Menguada sería la disciplina de un establecimiento en que se permitiera que entre compañeros de trabajo se injuriaren durante la jornada laboral. El respeto debe existir no solo hacia los superiores, sino entre iguales, jerárquicamente y para los inferiores". Con todo, este criterio jurisprudencial tuvo algunas excepciones. Por ejemplo, la sentencia de la Corte de Apelaciones de Santiago de 25 de enero de 1995, llegó a la conclusión de que las injurias proferidas por los trabajadores en contra de un tercero "que no es ni representa a la empresa, impiden al empleador invocar la causal de terminación del contrato, por ser evidente que aquellas no fueron dirigidas contra el empleador”. GJ No 175 (1995), p. 164. Este último caso jurisprudencial se refería a las injurias que dos trabajadores habían formulado en contra de un contador de la empresa. No obstante, al no ser éste representante ni trabajador dependiente 
de la ofensa, a los dependientes por cuenta ajena del empleador ${ }^{21}$, a los trabajadores de otra empresa que se vinculaban con aquella a la cual pertenece el trabajador (v. gr., injurias dirigidas en contra de trabajadores del contratista o de trabajador pertenecientes a una EST) ${ }^{22}$, a los clientes de la empresa e, incluso, parte de la jurisprudencia comparada lo ha extendido al abogado del empleador, y a vecinos de un inmueble que se ven afectados por actos injuriosos de un portero ${ }^{23}$. Como se puede observar, se trataba de una construcción bastante alejada de la injuria penal toda vez que la víctima directa de la ofensa no es la contraparte (empleador), sino que un tercero.

En la actualidad, la redacción utilizada por el Código dificulta una conclusión tan amplia como la que se ha esbozado en los párrafos anteriores. Una fuerte argumentación de texto podría llevar a concluir que el único sujeto pasivo de la injuria puede ser el empleador o sus representantes, ya que la reforma introducida por la Ley $\mathrm{N}^{\circ} 19.759$ buscaba precisamente centrar el ilícito en relación con los sujetos del contrato. En el fondo, lo que subyace en esta delimitación de la causal es evitar que el empleador utilice cualquier pretexto para desvincular al trabajador por actos que no tienen mayor conexión con el ámbito laboral.

Con todo, si se aceptara sin más este criterio limitativo lo cierto es que la injuria dirigida en contra de compañeros de labores igual podría configurarse como un incumplimiento grave de las obligaciones que impone el contrato de trabajo; pues dentro del contenido obligacional debe entenderse incluido el deber de respeto mutuo necesario para una adecuada convivencia y ejecución de las labores. Si el fundamento para sancionar laboralmente a los actos injuriosos es la necesaria y mínima armonía que debe existir en el ámbito organizativo del empleador, y la consecuente disciplina interna, no cabe duda que con ello se abarca también a las relaciones que se mantengan con el resto del personal e incluso con otras personas que se vinculan con el empleador en el contexto de la realidad laboral. El contrato de trabajo exige para ambos contratantes normas de conducta compatibles con las obligaciones laborales. De allí que, pretender que un contratante está habilitado para realizar actos injuriosos en relación con personas distintas del empleador, en el contexto de la relación laboral, y sin más consecuencia que las reglas generales del orden jurídico, pugna con el núcleo definitorio de la causal del artículo $160 \mathrm{~N}^{\circ} 7 \mathrm{CT}^{24}$. Por cierto, para aplicar esta causal se requiere que el acto en cuestión reúna las exigencias de gravedad a que se refiere el Código.

del empleador, se desestimó la legitimación del despido en razón de la causal de injurias. Más aún, la Corte concluyó en aquella oportunidad que era presupuesto ineludible para justificar la aplicación de la causal el que la injuria se hubiese dirigido en contra del empleador o alguno de sus representantes.

${ }^{21}$ Cfr., Gómez Abelleira, F. J., "Las causas disciplinarias del despido”, en Antonio V. Sempere Navarro (director), El despido, Aranzadi-Thomson Reuters, $2^{a}$ edición, Pamplona 2009, p. 232.

${ }^{22}$ Cfr. Igartúa Miró, M. T., "Ofensas verbales o físicas”, en Juan Gorelli Hernández (coord.), El despido: análisis y aplicación práctica, Tecnos, Madrid 2004, p. 99.

23 Vid. Aguilera Izquierdo, R., Las causas del despido disciplinario y su valoración por la jurisprudencia, Aranzadi, Pamplona 1997, p. 190; y Saavedra Acevedo, cit., p. 104.

${ }^{24}$ Cfr. en esta línea la sentencia de la Corte Suprema de 28 de julio de 2005 . GJ 301 (2005), p. 226. En dicha causa se sancionó a una trabajadora que mantenía fuertes discusiones con otra compañera de laborales, cuestión que provocó un incidente que atrajo la comparecencia de Carabineros. La Corte Suprema casó de 
La postura anterior cuenta con respaldo en determinados pronunciamientos de la jurisprudencia. Ese es el caso de la sentencia de 14 de marzo de 2007 de la Corte de Apelaciones de Punta Arenas ${ }^{25}$. En dicha ocasión, una trabajadora había sido despedida por proferir injurias a una compañera de labores; no obstante, la carta de despido fundamentó el acto extintivo precisamente en la causal del artículo $160 \mathrm{~N}^{\circ} 1$, letra d) CT. El tribunal de primera instancia acogió la demanda por despido injustificado, argumentando que el empleador en su carta de despido no hizo expresa referencia a la hipótesis del art. $160 \mathrm{~N}^{\circ} 7$ CT sino que a la del art. $160 \mathrm{~N}^{\circ} 1$, letra d) CT. En razón de lo anterior, según el tribunal, la causal no le era aplicable al trabajador, ya que la norma solo sancionaba las injurias dirigidas al empleador y no a los compañeros de labores.

Conociendo del recurso respectivo, la Corte de Punta Arenas revocó el fallo y le restó valor a la errónea invocación de causal. Por lo tanto, y amparándose en el hecho de que en la contestación de la demanda sí se había argumentado la eventual infracción al art. $160 \mathrm{~N}^{\circ} 7 \mathrm{CT}$, la Corte estimó que las injurias proferidas en contra de un compañero de trabajo es suficiente fundamento para extinguir el contrato por incumplimiento grave de las obligaciones ${ }^{26}$.

\subsection{El sujeto activo de la injuria}

Como se ha dicho, la causa de extinción contractual está referida esencialmente al trabajador. Si, eventualmente, fuese el empleador el autor del acto injurioso entonces procedería aplicar el procedimiento propio del despido indirecto consagrado en el artículo $171 \mathrm{CT}$.

oficio la sentencia de la Corte de Apelaciones y confirmó los considerandos $6^{\circ}$ y $7^{\circ}$ del fallo de primer grado según el cual las conductas de la trabajadora despedida alteraban "gravemente la disciplina laboral, como también la actividad comercial de la empleadora". En efecto, dijo la Corte, "la venta de ropa de señora, requiere necesariamente de un ambiente normal y de trato deferente entre todos los participantes de la actividad, esto es, dependientes y clientela, de lo contrario esta última mermará en favor de otro establecimiento". En el ámbito de la doctrina nacional, Vid. también Macchiavello Cúneo, G., Derecho del Trabajo T. I, Fondo de Cultura Económica, Santiago 1986, p. 519, quien incluso considera que este tipo de figuras pueden ser sancionadas como un supuesto de conducta inmoral grave.

${ }^{25}$ Causa Ingreso Corte $\mathrm{N}^{\mathrm{O}} 2-2007$.

${ }^{26}$ Sentencia de la Corte de Apelaciones de Punta Arenas de 14 de marzo de 2007 (Causa Ingreso Corte No 2-2007): “60.- Que el contrato de trabajo, además de las cláusulas escrituradas que obligan a las partes, contiene algunas otras que la jurisprudencia ha denominado 'cláusulas éticas', que deben entenderse contenidas aunque no estén escritas, las que significan principalmente en el comportamiento tanto del trabajador como del empleador durante la faena, debiéndose entender comprendida entre las que corresponde al empleado la de respeto a sus superiores y compañeros de trabajo, y si bien la legislación sanciona con la terminación del contrato las injurias del trabajador al empleador, no se puede negar que también se encuentra comprendida en el contrato su obligación de no injuriar a sus compañeros, especialmente cuando se trata de una dama, y sobre todo cuando se dirigen hacia él en cumplimiento de sus propias labores y además son sus superiores que obran en representación del patrón; $7^{\circ}$.- Que así las cosas la circunstancia que motivó el despido, unida a las conductas que se amonestaron durante su desempeño, tipifican la causal de terminación del contrato de trabajo, sin derecho a indemnización alguna contemplada en el $\mathrm{N}^{\circ} 7$ del artículo 160 del Código del Trabajo, esto es, incumplimiento grave de las obligaciones que impone el contrato, causal, como se dijo, alegada por la demandada en su contestación de la demanda, por lo que se rechazará esta”. 
La redacción utilizada por el Código es taxativa: se trata de injurias proferidas por el trabajador. Dicha expresión es amplia y omnicomprensiva de cualquier sujeto que ocupe la posición jurídica del trabajador, independientemente de la categoría o cargo que ocupa dentro del entramado organizacional de una empresa. Desde esta perspectiva, el alto directivo también puede verse afectado con esta causal, ya sea que las injurias se las exprese a trabajadores que se encuentran sobre su cargo o bien bajo su subordinación organizativa.

No obstante, doctrinariamente también se ha aceptado que esta causal sea aplicada cuando la injuria es realizada por una persona allegada al trabajador y sin que este muestre su discrepancia con tal acto (siempre y cuando tenía la obligación contractual de hacerlo $)^{27}$. Igualmente, se acepta la aplicación de la causal cuando el trabajador ha concebido el plan ofensivo o ha instigado a su realización ${ }^{28}$. Esta idea tan amplia sobre el autor de la falta, convierte en difusa la figura del sujeto activo. De allí que lo aceptable es que se exija un factor causal que permita responsabilizar eventualmente al trabajador por un hecho ajeno, ya que en caso contrario podría terminar estableciéndose una especie de responsabilidad objetiva; cuestión que ciertamente no ocurriría si existe por parte del trabajador instigación, inducción, complicidad, incumplimiento grave de un deber contractual de discrepancia, o la aceptación tácita de los dichos injuriosos.

\section{El contenido de la infracción}

El Código del Trabajo, a diferencia de lo que ocurre en el ámbito penal, no ha definido a la injuria. Es como si el artículo 160 CT partiera de la base de que se trata de un concepto conocido y ampliamente aceptado en su intensidad y extensión. Esta carencia de un concepto legal específico ha permitido, en la práctica, que esta específica causal de despido sea aplicada a una serie de manifestaciones o comportamientos más o menos ofensivos, pero que en rigor podrían ser perfectamente imputados a otro tipo de infracciones (v. gr. amenazas, coacciones, imputación de delitos o incluso el acoso laboral o sexual) ${ }^{29}$.

Sin perjuicio de lo anterior, no cabe duda que la injuria, en materia laboral, se vincula con expresiones del trabajador que supongan ofensas (verbales o por escrito), que difamen, deshonren o menosprecien ya sea al empleador o, en los términos que ya se ha explicado, a algún trabajador de la empresa, o que dañe el honor, prestigio o valor del afectado ${ }^{30}$.

${ }^{27}$ Vid. Aguilera Izquierdo, cit., p. 207. Vid. también Sagardoy Bengoechea, J. A., El despido laboral y los expedientes de crisis, Ediciones Deusto, Bilbao 1969, p. 82.

${ }^{28}$ Cfr. Gómez Abelleira, cit., p. 240.

${ }^{29}$ Vid. Igartúa Miró, cit., p. 88.

${ }^{30}$ En palabras de la jurisprudencia: “(...) la injuria es la acción que implica afrenta o agravio, esto es, el dicho que ofende la honra o toda expresión proferida o acción ejecutada en deshonra, descrédito o menosprecio de otra persona" (sentencia de la Corte de Apelaciones de Concepción de 24 de octubre de 2003. Causa Ingreso Corte $\mathrm{N}^{\circ}$ 2663-2003): " $6^{\circ}$ Que las injurias (...) deben entenderse en su sentido natural y obvio, es decir, expresiones que agravian o ultrajan a otro, mediando obras o palabras que lo agravian" (sentencia de la Corte de Apelaciones de San Miguel de 21 de agosto de 1987. GJ No 87 (1987), p. 77). Vid., también, Goñi Sein, "Las ofensas", cit., p. 466: "La ofensa verbal es (...) la expresión oral o escrita que comporta un injusto 
Debe tratarse de ofensas concretas y determinadas, no ambiguas ${ }^{31}$, cuyo destinatario se encuentre claramente delimitado ${ }^{32}$. Desde esta perspectiva, la referencia del Código busca proteger el honor y la dignidad de las personas que trabajan en la empresa (en particular el empleador) en el entendido que la ofensa menoscaba estos bienes jurídicos. ${ }^{33}$

La expresión injuria tiene una clara connotación penal. No obstante, es evidente que entre la injuria laboral y la penal existen marcadas diferencias. Así lo han ratificado en diversas oportunidades tanto doctrina como jurisprudencia, las cuales delimitan las particularidades de la infracción laboral ${ }^{34}$. En este orden de ideas, a la injuria laboral no se le pueden exigir los mismos y exigentes requisitos técnicos que meticulosamente ha regulado el Código penal, ya que ello implicaría asimilar la infracción a la mera comisión de un delito. Por el contrario, todo parece indicar que la expresión contenida en el Código del Trabajo engloba a un conjunto de situaciones que van más allá del ilícito penal ${ }^{35}$.

ataque a la persona (o entidad empresarial) ofendiéndola en su honor o vejándola en su dignidad personal, presuponiendo en todo caso la existencia de una acción ejercida en deshonra, descrédito o menosprecio".

${ }^{31}$ Cfr. Ortiz Lallana, M. C., "Causas y formas del despido disciplinario (en torno a los artículos 54 y 55)", en El Estatuto de los Trabajadores veinte años después, Civitas, $1^{a}$ edición, Madrid 2000, p. 1131. En igual sentido, con relación eso sí con la Ley Federal del Trabajo de México, Vid. De Buen L., N., Derecho del Trabajo T. II, Porrúa, $1^{a}$ edición, México DF 1992, p. 93.

32 Vid. en este sentido la sentencia de la Corte de Apelaciones de Concepción de 21 de abril de 2004. GJ N 291 (2004), p. 202: “1. Que la discusión se ha centrado en estos autos, tal como lo señala el juez de primera instancia en el considerando tercero de la sentencia aludida, en determinar si la carta dirigida por el actor a su jefe contiene o no expresiones injuriosas que hagan justificable el despido de que fue objeto aquel. $2^{\circ}$. Que una lectura somera del documento en cuestión pone de manifiesto que el trabajador atribuye a su superior jerárquico actitudes pasivas o silencios permisivos frente a delitos que enumera y detalla cometidos bajo su administración, conductas que lo aproximan a una suerte de complicidad o encubrimiento de tales ilícitos. En efecto, en dicha carta además de reclamarle por lo que estima violación a la privacidad de sus colaboradores que no son ni sus esclavos ni sus empleados, sino que prestan servicios a la empresa C.T.R. S.A., agrega en párrafo aparte: "Considero francamente poco leal y poco objetiva su actitud Sr. López, toda vez que, bajo su administración se han cometido verdaderos fraudes y grandes robos con enormes perjuicios para esta Compañía y su actitud fue diametralmente opuesta a la de hoy en un tema tremendamente insignificante frente a los hechos que le recordaré'. (...). $3^{\circ}$. Que las expresiones vertidas en la carta que sirve de basamento al despido, sobrepasa los límites de una falta de respeto, compromete gravemente el vínculo de subordinación que debe existir entre un trabajador y su empleador, afectando la honra de este último. El animus injuriandi o intención de injuriar queda evidenciado con el envío que hizo el actor de una copia de esta carta al gerente regional del la VIII Región, a la gerente de finanzas y al gerente comercial de la empresa, hecho consignado en la carta de despido y no rebatido por el demandante".

${ }^{33}$ Vid. Aguilera Izquierdo, cit., p. 191. La propia jurisprudencia se ha encargado de señalar que el derecho al honor es un atributo de la personalidad de la mayor importancia y de carácter especialísimo, por lo que debe gozar de preeminencia sobre otros derechos (sentencia de la Corte Suprema de 16 de julio de 2003). RDJ, T. C, sección quinta (2003), p. 113. Un criterio más matizado del derecho al honor se encuentra en la sentencia del Tribunal Constitucional de 7 de junio de 2012 ( $\operatorname{Rol~N}^{\circ} 2085-2011$ ).

${ }^{34}$ Vid., por todos, Goñi Sein, "Las ofensas”, cit, p. 467: “(...) no es preciso que las ofensas merezcan la calificación jurídica de delito o falta, y la causa, incluso, puede seguir operando aunque haya habido una absolución o sobreseimiento en el proceso penal".

${ }^{35}$ Vid. en esta misma línea Alonso Olea, M., y Casas Baamonde, M. E., Derecho del Trabajo, Servicio de Publicaciones Facultad de Derecho Universidad Complutense de Madrid, 13a edición, Madrid 1994, p. 439: "No es necesario que el hecho constituya delito o falta; puede incluso seguir operando como causa de despido aun en casos de absolución o sobreseimiento en proceso penal”. 
La configuración de esta infracción, en el contexto del despido disciplinario, es amplia y variada. Dentro de la injuria se recogen en primer término las expresiones, verbales o escritas, que supongan una variada tipología de insultos, ofensas, agravios, ultrajes de obra o de palabra, la negación de una cualidad cuya ausencia rebaja a la persona, la imputación de hechos falsos o incluso el menosprecio al ofendido mediante frases o actos despectivos ${ }^{36}$. También se han agregado dentro de la hipótesis de la injuria la realización de gestos obscenos, las respuestas burlonas, las amenazas, los actos despreciativos ${ }^{37}$. En el fondo, se busca englobar dentro del núcleo definitorio de la infracción cualquier actitud vejatoria o humillante que suponga un menosprecio de la dignidad del sujeto en contra del cual va dirigida la expresión.

En rigor, esta configuración permite, eventualmente, el encuadre de la causal con el núcleo definitorio de los delitos de injuria o calumnia, pero no se agotan en dichos ámbitos. Es decir, una expresión injuriosa puede constituir una infracción laboral pero no necesariamente habrá de cumplir los requisitos que para este tipo de figuras exige el Código Penal ${ }^{38}$. Lo que se quiere decir es que aun cuando la injuria es una figura rigurosamente delimitada en el orden penal, en materia laboral se le invoca de forma genérica e independientemente de si cumple o no con el estándar penal.

\subsection{La objetividad de la ofensa}

El artículo $160 \mathrm{~N}^{\circ} 1 \mathrm{CT}$ exige que las injurias sean proferidas, en una clara repetición del artículo 416 del Código Penal. Si bien es cierto que el Código se refiere a esta infracción en plural, ello no debe ser entendido como una exigencia de magnitud cuantitativa. La gravedad de una ofensa puede verificarse por la ocurrencia de un solo acto o bien por la reiteración del injusto ${ }^{39}$. De esta forma, lo relevante en la regulación legal es la envergadura del acto injurioso que puede reflejarse en una situación específica de entidad suficiente o bien en la repetición reiterada de la conducta (de lo cual puede derivarse la gravedad). Dicho de otro modo, la referencia que utiliza el Código del Trabajo se refiere genéricamente a las múltiples modalidades del maltrato de palabra, y no a la pluralidad de este ${ }^{40}$.

${ }^{36}$ Vid, Aguilera Izquierdo, cit., p. 192. Vid. también Gómez Abelleira, cit., p. 230.
${ }^{37}$ Cfr. Cabanellas, G., Tratado de Derecho Laboral, T. II, Vol. 3, Heliasta, $3^{\text {a }}$ edición, Buenos Aires 1988 , p. 213.

${ }^{38}$ En palabras de Montoya Melgar, A., Derecho del Trabajo. Tecnos, $29^{a}$ edición, Madrid 2008, p. 472: "La responsabilidad laboral por estas actuaciones procede, lógicamente, con independencia de la posible punibilidad penal de las mismas".

${ }^{39}$ Cfr. por todas sentencia de la Corte de Apelaciones de Santiago de 8 de enero de 1988. RDJ, T. LXXXV, sección tercera (1988), p. 34. Vid. también sentencia de la Corte de Apelaciones de Santiago de 5 de agosto de 2008. GJ No 338 (2008), p. 282.

${ }^{40}$ Cfr., en el plano doctrinal, Gárate Castro, cit., p. 188; y Gómez Abelleira, cit., p. 233. Lo anterior se diferencia, por cierto, de la regulación del acoso laboral que efectúa la Ley $\mathrm{N}^{\circ} 20.603$, de 8 de agosto de 2012. En este último caso, el artículo $2^{\circ} \mathrm{CT}$ exige que la agresión u hostigamiento sean reiterados, y "que tenga como resultado para el o los afectados su menoscabo, maltrato o humillación, o bien que amenace o perjudique su situación laboral o sus oportunidades en el empleo". 
Desde una perspectiva lingüística, la voz injuria y el verbo "proferir" se encuentran muy vinculados a la articulación de palabras o sonidos; pero en rigor, su alcance es mayor. La figura que se busca sancionar en el ámbito laboral es aquella que consiste en una acción u omisión injuriosa en sentido amplio ${ }^{41}$. El comportamiento activo resulta fácil de acreditar; sin embargo, en el caso de la omisión será necesario que el trabajador se encuentre en una posición de garante con relación al empleador. Por ejemplo, cabría dentro de esta alternativa (vinculada a la omisión) la circunstancia de que el trabajador deje al empleador con la mano estirada, en aquellos casos que está obligado a guardar ciertas formalidades de respeto o tratamiento respecto a este ${ }^{42}$. También podrían incorporarse dentro de este grupo la ridiculización simuladamente lúdica o la ejecución de morisquetas $^{43}$. Lo relevante, es que el acto en cuestión tenga un carácter marcadamente ofensivo o vejatorio, aun cuando no necesariamente se requiere la obtención de un resultado lesivo propiamente tal. Es decir, la expresión se presenta rodeada de tal nivel de elementos que objetivamente habrá de concluirse la existencia de un acto indebido que perjudica la convivencia al interior de la empresa. En este contexto, cabrían dentro de la hipótesis las denominadas injurias encubiertas tales como los movimientos, las alegorías, caricaturas emblemáticas o alusiones vejatorias en contra del empleador; las denominadas injurias oblicuas o simbólicas, y las injurias larvadas ${ }^{44}$.

Por cierto, la evaluación de la ofensa dependerá del contexto en que ella se emita. De allí que se haya estimado que, dependiendo de la naturaleza de las labores y el ámbito en que ellas se realizan, las contestaciones en forma aparentemente irrespetuosa no constituyen de por sí una actitud que deba ser catalogada a priori dentro de la injuria laboral ${ }^{45}$. Más aún, la naturaleza de la actividad admite en variadas ocasiones el uso de términos que, en otros ámbitos, serían ciertamente reprobables ${ }^{46}$. De allí que la doctrina haya

${ }^{41}$ Vid. el alcance que se le otorga a estas palabras en el ámbito penal, en Etcheberry, cit., T. III, p. 115.

${ }^{42}$ Vid. la solución dada a esta problemática, por la doctrina penal, en Garrido Montt, M., Derecho Penal, T. III, Editorial Jurídica de Chile, 4ª edición, Santiago 2010, p. 200.

43 Vid., a mayor abundamiento, la situación descrita por Martínez Girón, J., El despido en el Derecho de los Estados Unidos. Civitas, $1^{a}$ edición, Madrid 1988, p. 87, nota 208, con relación a la negativa a recibir regalos. En efecto, según la jurisprudencia norteamericana, "no revela falta de respeto 'negarse a aceptar un regalo del empresario' pues 'la aceptación de un regalo..., o incluso de un incremento de salarios, no pueden forzarse en derecho, sino que deben ser enteramente voluntarias"”.

${ }^{44}$ Sobre el alcance de cada una estas alternativas, en el ámbito penal, Vid. Etcheberry, cit., T. III, p. 116; y Garrido Montt, cit., T. III, p. 200.

${ }^{45}$ Cfr. Baylos Grau, A., "La valoración del comportamiento habitual del trabajador en el despido por malos tratos y faltas graves de respeto", RPS N 119 (1978), p. 245. Cfr. además Moreno de Toro, C., "Poder disciplinario, proporcionalidad y discrecionalidad en la imposición de las sanciones". TL No 101 (2009), p. 261. Vid. también sentencia de la Corte Suprema de 4 de noviembre de 1981. RDJ, T. LXXVIII (1981), sección tercera, p. 107: "la causa justificada de terminación del contrato de trabajo constituida por injurias no puede entenderse conformada por una conversación en que el trabajador despedido dijo a un compañero de trabajo, en tono de broma, que su jefe no lo atendió por encontrarse ebrio, ya que este hecho no reviste la gravedad suficiente para estimar que con esas expresiones se estaba injuriando a dicha persona”.

${ }^{46}$ Este criterio es el que se esgrime en la sentencia de la Corte de Apelaciones de La Serena de 29 de diciembre de 2003 (Causa Ingreso Corte No 2600-2003): "Es preciso tener presente, además, para evaluar la gravedad de la conducta indebida reprochada al actor, la circunstancia de que esta se manifestó en una 
advertido que el carácter ofensivo de las palabras varía con el tiempo: "palabras que en otros momentos podían tener un significado ofensivo hoy carecen de él" 47 .

El contexto laboral de la injuria se tiende a aceptar sin mayores reparos cuando la ofensa se produce en el lugar de trabajo o durante la jornada laboral ${ }^{48}$. Con todo, en determinados casos, se ha admitido la existencia de un acto injurioso fuera del lugar de trabajo o de la jornada propiamente tal cuando este se ha ejecutado en un contexto íntimamente asociado a la actividad laboral ${ }^{49}$. Como ya se ha dicho, el análisis de las ofensas proferidas en un ámbito extralaboral tiene que partir por el reconocimiento general de que, en principio, resultan irrelevantes las actuaciones ejecutadas por el trabajador fuera del contexto propio del contrato de trabajo ${ }^{50}$. No obstante, en el caso de las injurias, se

celebración de trabajadores agrícolas, con la consabida ingesta de alcohol, probablemente en exceso, en que el empleo de palabrotas o garabatos pasa a formar parte del lenguaje normal, acentuada esta situación con ocasión del altercado que refieren los testigos de la parte demandada". En igual sentido, sentencia de la Corte Suprema de 4 de febrero de 1992. BDT No 56 (1993), p. 81: "La discusión de palabra aun en términos groseros, propios del lenguaje usado en tales casos, no puede ser estimado como falta de probidad"; y la sentencia de la Corte de Apelaciones de Santiago de 6 de mayo de 1994. RDJ, T. XCI, sección tercera (1994), p. 135: "Las expresiones soeces que tuvo el demandante para con su jefe, si bien son reprochables, ellas no son constitutivas de injuria o de conducta inmoral grave, atendido el hecho del nivel cultural del trabajador y la habitualidad del uso de expresiones incorrectas e inadecuadas en dicho estrato socioeconómico de la población, debiendo considerarse, además, que es la única oportunidad en cinco años de trabajo, que el actor usó tales expresiones”. Una posición doctrinaria semejante puede consultarse en Gómez Abelleira, cit., p. 229: "la ofensa debe distinguirse de la utilización de un lenguaje soez o malsonante o del trato desabrido y descortés, sin perjuicio de que la reiteración de estos comportamientos contrarios a las reglas de la educación pueda determinar la procedencia del despido por el clima desagradable que crean (...)". Una posición diversa en lo que respecta al uso de términos soeces se encuentra en la sentencia de la Corte de Apelaciones de Valparaíso de 1 de marzo de 1995 (Causa Ingreso Corte No 401-1994): "Que no obsta a lo concluido lo afirmado por el sentenciador de primera instancia, en el sentido que las expresiones empleadas por el trabajador no serían injuriosas, sino 'garabatos vulgares de uso popular en la jerga de nuestro pueblo', por cuanto el propio demandante confiesa haber dicho a su superior 'que él era un poco hombre y que era dominado por la maestra de cocina'. Este juicio emitido por el actor, airadamente y con palabras soeces y no con las expresiones empleadas en la absolución de posiciones, constituye una injuria al administrador y no el simple empleo de palabras vulgares en un trato normal de personas de nuestro pueblo, más aún si se observa que correspondió a la respuesta a un llamado de atención”. En una orientación similar, vid sentencia de la Corte Suprema de 28 de enero de 2009 (Causa Ingreso Corte No 7698-2008).

47 Vid. Aguilera Izquierdo, cit., p. 195.

${ }^{48}$ Cfr. García Ninet, cit., p. 191. En el plano jurisprudencial, Vid. por todas sentencia de la Corte de Apelaciones de La Serena de 29 de diciembre de 2003 (Causa Ingreso Corte No 2600-2003).

49 A nivel comparado, excepcionalmente algunas legislaciones han aceptado sancionar las injurias proferidas fuera del servicio. Ese es el caso, por ejemplo, del artículo 47, fracción IV, de la Ley Federal del Trabajo de México (1970), el cual sanciona entre otros los actos de injuria del trabajador "fuera del servicio, contra el patrón, sus familiares o personal directivo administrativo, (...), si son de tal manera graves que hagan imposible el cumplimiento de la relación de trabajo". Distinto es el caso de Brasil, en que el artículo 482 letra j) de la Consolidación de Leyes del Trabajo (1943) solo sanciona los actos lesivos de la honra o buena fama ejecutados "en el servicio" contra cualquier persona. Con todo, si el sujeto pasivo es el empleador o un superior jerárquico, entonces no se establece la exigencia de que el acto injurioso se haya cometido "en el servicio" (art. 482 letra k).

${ }^{50}$ Cfr. Goñi Sein, "Las ofensas”, cit., p. 472; y Rojas Rivero, cit., p. 77. Desde luego, el empleador no podría invocar las declaraciones vertidas por un trabajador en calidad de testigo en un proceso judicial. Así lo ha reconocido expresamente la jurisprudencia, pues se parte de la base que dicha actuación se ha 
consideran sancionables aquellas ofensas que aun cuando se profieren fuera del ámbito de la empresa o de la jornada de trabajo, igual reconocen una motivación y vínculo laboral. Esta motivación exige reconocer que el acto injurioso tiene por causa exclusiva el contrato de trabajo; en caso contrario, los actos pertenecientes a la vida extralaboral no pueden llegar a tener relevancia disciplinaria ${ }^{51}$.

\subsection{El elemento subjetivo}

La concurrencia de un acto injurioso requiere no solo de voluntariedad sino que, además, de un claro animus injuriandi. La concurrencia de este ánimo es esencial, pues en definitiva ello permitirá resolver el verdadero sentido o alcance de expresiones aparentemente injuriosas. Como se ha dicho en materia penal ${ }^{52}$, pero aplicable a la esfera laboral, el simple proceso de constatación de hechos no basta, ya que sobre el sentido literal de las palabras debe prevalecer la intención con que ellas se pronuncian. En consecuencia, cuando se intenta aplicar la causal de injurias ella termina enfocándose hacia toda falta de respeto, ejecutadas en forma despectiva, despreciativa y altamente ofensiva, con el expreso ánimo de injuriar. Y si falta ese ánimo, difícilmente podrá configurarse la causal. Ese sería el caso, por ejemplo, de las palabras aparentemente injuriosas pronunciadas por un trabajador extranjero que desconoce los alcances del idioma, o el supuesto de la

verificado fuera del lugar de trabajo. Vid. en esta línea sentencia de la Corte Suprema de 27 de marzo de 2006. GJ No 309 (2006), p. 282, la cual concluye que el empleador no puede utilizar declaraciones judiciales prestadas por sus trabajadores en un juicio laboral para justificar una causal de despido: “Además, no pueden considerarse constitutivas de injurias las declaraciones otorgadas por un trabajador en calidad de testigo de un juicio para efecto de acreditar sus dichos. Adicionalmente, si las expresiones consideradas injuriosas no fueron efectuadas en el lugar de trabajo sino que fuera de la empresa, ante un Tribunal de la República, y que la parte demandada habiendo hecho reserva de acciones para querellarse criminalmente en contra de la demandante no lo hizo, no se configura la causal del artículo 160 número 1 letra d) del Código del Trabajo”.

${ }^{51}$ Esa es la lógica que sigue la sentencia de la Corte de Apelaciones de La Serena de 29 de diciembre de 2003 (Causa Ingreso Corte N N 2600-2003), la cual excluye de responsabilidad injuriosa las expresiones vertidas por un trabajador en un "asado" de la empresa: "Que se encuentra implícito en la causal de caducidad de contrato que se analiza, que el hecho se produzca dentro del ámbito laboral, lo que significa, por regla general, que acaezca en el lugar de trabajo y dentro de la jornada laboral, lugar y tiempo en que se encuentran plenamente vigentes los derechos y obligaciones recíprocos que nacen de la relación laboral entre trabajador y empleador. Que los hechos que se dan como fundamento de la causal de despido invocada en este juicio ocurrieron durante una convivencia realizada fuera de la jornada, consistente en un asado, convivencia a la que concurrió como invitado el demandante (pues no pertenecía a ese grupo de trabajo), y a la cual llegó más tarde, también como invitado, el administrador de la hacienda. En cuanto al lugar, si bien el asado se realizó en dependencias de la hacienda, lo fue en una cancha de futbol que hay dentro de ella, espacio que no cabría considerar como lugar de trabajo". Sobre la influencia que tiene el lugar en lo que respecta a la calificación del acto, Vid. también sentencia de la Corte del Trabajo de Santiago de 9 de abril de 1980. RDJ, T. LXXVII (sección tercera), p. 54: "El hecho de que el actor, al momento de la discusión no se encontrare en su horario de trabajo, es, hasta cierto punto, indiferente en el problema deducido. Y podría considerarse un agravante, puesto que, no estando obligado a presentarse en la industria, lo hizo y faltó el respeto que debe a sus compañeros o superiores, sin motivos justificados".

${ }^{52}$ Vid. Labatut Glena, G., Derecho Penal T. II. Editorial Jurídica de Chile, 7ª edición, Santiago 1996, p. 184 . 
ofensa originada en una agresión previa al trabajador en la cual se busca responder a una provocación más que desplegar un determinado animus ${ }^{53}$. También harían desaparecer la ilicitud de la expresión cuando esta es proferida en razón de un deseo de divertir, de corregir o bien de informar o aconsejar, entre otros.

La existencia del animus injuriandi debe ser probado en sede judicial, aun cuando no cabe duda de que en muchos casos la "idoneidad deshonrosa (es) tan evidente que dejan apenas margen de duda a la existencia del propósito injurioso" ${ }^{54}$. Hay expresiones o gestos que son de por sí injuriosos, aun cuando en estos casos se termina presumiendo la existencia del animus injuriandi debido a la gravedad de la expresión ${ }^{55}$.

En materia laboral, la exigencia de un especial ánimo de injuria se ha estructurado como un requisito ampliamente asumido por la jurisprudencia aun cuando de calificación más flexible que la exigida en el ámbito penal. Lo anterior no implica que la ofensa deba estar desprovista de un especial ánimo de injuriar ${ }^{56}$; simplemente, la valoración de ese ánimo así como la configuración de la infracción tiende a ser en la práctica técnicamente menos rigurosa que aquella que se ocupa en sede penal ${ }^{57}$.

${ }^{53}$ Cfr. Saavedra Acevedo, cit., p. 94: "No puede considerarse constitutiva de malos tratos la conducta del trabajador que se limitó, a causa de tantas provocaciones, a rechazar la agresión verbal de que fue objeto, cediendo a un impulso natural y humano de rechazar aquello que arbitraria e injustamente pone en entredicho y lesiona la dignidad de la persona”. Y agrega: "La prioridad agresiva tiene que constar claramente (...). Por supuesto, el acto de provocación debe ser grave (...)". Vid. también Baylos Grau, "Algunas Constantes”, cit., p. 354; y Gómez Abelleira, cit., p. 243. En el plano jurisprudencial, vid, sentencia de la Corte Suprema de 15 de diciembre de 1958. RFM No 3, enero (1959), p. 5, la cual concluyó que para admitir la terminación de un contrato de trabajo, por injurias, resulta esencial que las expresiones vertidas verbalmente o por escrito, lo sean en deshonra, descrédito o menosprecio del empleador "y exista animus injuriandi. En la especie, se trata de una crítica movida por actos políticos, la que por acerba que sea no constituye una injuria”.

${ }^{54}$ Vid. García Ninet, cit., p. 175. Y agrega en p. 188: “(...) hay ciertas expresiones que son de tal punto insultantes de por sí que son objetivamente ofensivas, sin que haya necesidad de demostrar o probar el específico ánimo injurioso (...)”. En igual sentido, cfr. Igartúa Miró, cit., p. 94.

${ }^{55}$ Cfr. Labatut Glena, cit., p. 184.

${ }^{56}$ Cfr. Goñi Sein, "Las ofensas", cit., p. 468; y Gárate Castro, cit., p. 189. Vid. también sentencia de

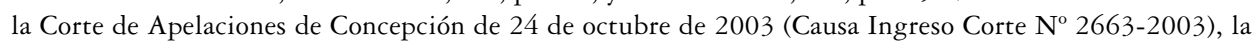
cual parte de la base que el ánimo de injuriar es un elemento esencial de la causal extintiva; más aún, según este fallo, cualquier discusión por fuerte que sea, puede suponer falta de respeto, pero no intención de restar crédito a la honra del jefe afectado. Ese mismo criterio, en orden a restarle gravedad a las meras faltas de respeto, puede consultarse en la sentencia del Tribunal de Alzada de Santiago de 29 de diciembre de 1942 , en Repertorio de Legislación y Jurisprudencia Chilenas. Código del Trabajo T. I. Editorial Jurídica de Chile, Santiago 1958, p. 93: "Una mera falta de respeto hacia los superiores no produce la caducidad del contrato".

${ }^{57}$ Cfr. sentencia de la Corte de Apelaciones de San Miguel de 21 de agosto de 1987. GJ No 87 (1987), p. 77: "Las injurias que la ley laboral señala como suficiente para justificar el despido de un trabajador, debe entenderse en su sentido natural u obvio y no en el técnico que configura el delito previsto en el Código Penal". Un criterio algo diverso puede observarse en la sentencia de la Corte Suprema de 1 de julio de 2009 (Causa Ingreso Corte N ${ }^{\circ}$ 2654-2009), la cual concluye que "la injuria al empleador que constituye la causal de despido citada en el presente caso, al igual que ha sido definida en el ámbito penal, importa una expresión proferida o una acción ejecutada en deshonra, descrédito o menosprecio de aquel o de sus representantes en la línea de mando y que conlleva, por ende, la inequívoca intención de lograr ese fin. La concreción de dicho objetivo, sin embargo, plantea en el contexto laboral la necesidad de un análisis caso a caso que conduzca indefectiblemente a un ánimo de denostar a los superiores debido a las circunstancias específicas del hecho con relación a un determinado ambiente de trabajo". 
Con todo, hay elementos que atenúan o agravan la conducta y que afectan la voluntariedad del acto. Por ejemplo, el contexto público o privado de la ofensa no constituye un elemento gravitante para configurar la existencia de la causal, aun cuando se le acepta como un factor de agravamiento de la falta: si las frases son de por sí ofensivas y se realizan delante de alguna de las personas mencionadas, se asume la gravedad de la falta cometida y de los perjuicios que la misma causa al empleador. Asimismo, circunstancias tales como el nivel cultural del sujeto que profiere la injuria, la posición que se ocupa en la organización o bien el hecho de que las ofensas se lleven a cabo de forma escrita y con publicidad, ratifican la intencionalidad injuriosa y agravan la calificación del acto ${ }^{58}$.

Por el contrario, doctrina y jurisprudencia han señalado que no se configura esta causal cuando existen antecedentes que compensan una reacción de esta naturaleza, cuando se desarrollan labores que ponen nervioso al trabajador o cuando existe confianza con el empleador ${ }^{59}$. Por ejemplo, el advertir un trabajador a su empleador, que a la vez es su amigo, que lo tenía aburrido, si bien es una falta de respeto hacia este no alcanza a constituir una actitud sancionable desde la óptica del despido disciplinario pues, aparte de no existir un animus injuriandi, el comentario se efectuó dentro de márgenes de amistad o cercanía 60 . Asimismo, la existencia de un "clima de tensión” provocado por conductas antijurídicas de la empresa, la circunstancia de encontrarse el trabajador bajo los efectos de una depresión o en estado de ansiedad ${ }^{61}$, los justos reclamos ${ }^{62}$, la anti-

${ }^{58}$ Cfr. entre otros Aguilera Izquierdo, cit., pp. 203 y 204; Gárate Castro, cit., p. 189; García Ninet, cit., p. 176; Igartúa Miró, cit., p. 97; Rojas Rivero, cit., p. 94; y Saavedra Acevedo, cit., p. 104. Vid. a mayor abundamiento la sentencia de la Corte del Trabajo de Santiago de 9 de abril de 1980. RDJ, T. LXXVII sección tercera (1980), p. 54: "La calidad de quien profiere una expresión y las circunstancias en que ella es empleada hacen que constituya injuria y justifique el despido del trabajador que la profiere (...)".

59 Vid. por todos Baylos Grau, "La valoración”, cit., pp. 243 y ss.

${ }^{60}$ Cfr. sentencia de la Corte Suprema de 4 de enero de 1984 (Causa Ingreso Corte No 4994); y sentencia de la Corte de Apelaciones de Antofagasta de 11 de noviembre de 1983. En Thayer Arteaga, W., y Rodríguez Alvarado, A., Código del Trabajo y Legislación Social, Editorial Jurídica de Chile/Editorial Jurídica Ediar Cono-Sur Ltda., Santiago 1988, p. 322. Vid. además sentencia de la Corte Suprema de 30 de septiembre de 1996 (Causa Ingreso Corte $N^{\circ}$ 2922-1996): “(...) las expresiones que se ha dado por establecido que fueron inferidas por el actor, no pueden considerarse injuriosas en los términos del art. $160 \mathrm{~N}^{\circ} 1$ del Código del Trabajo, toda vez que lo natural entre personas que efectúan labores como aquellas materia del contrato, como también entre compañeros, es la utilización de frases directas y de términos francos, sin que su empleo implique injuria, menoscabo o desprecio”.

${ }^{61}$ Cfr. Gómez Abelleira, cit., p. 241. Un comentario adicional requieren las injurias proferidas en estado de embriaguez. Por regla general, el estado de ebriedad tiende a no ser considerado como atenuante, salvo que se trate de una embriaguez no habitual en cuyo caso la jurisprudencia ha estimado, en la mayoría de los casos, que se carece de la gravedad y relevancia necesaria para extinguir el contrato (cfr. por todas sentencia de la Corte Suprema de 4 de septiembre de 1997. RDJ., T. XCIV, sección tercera [1997], p. 130). No obstante, aun en este último supuesto, se acepta la gravedad de la conducta cuando el estado de ebriedad lesiona seriamente -y para casos muy específicos- la imagen externa de ciertas entidades, o bien cuando la conducta del ebrio genera un escándalo que afecta la ponderación y prudencia impuesta por las circunstancias. Sobre el particular, Vid. Irureta Uriarte, P., "La falta de probidad como causa de extinción del contrato de trabajo", en Libro homenaje al profesor William Thayer Arteaga. Editado por Sociedad Chilena de Derecho del Trabajo y Seguridad Social, Santiago 1998, pp. 124 y ss.

${ }^{62}$ La jurisprudencia del Código de 1931 ya asumía este tipo de atenuantes al indicar que las “injurias proferidas por el empleado no producen la caducidad del contrato, cuando existen a su favor circunstancias 
güedad en el empleo ${ }^{63}$ el arrepentimiento espontáneo ${ }^{64}$, o el simple mal genio habitual del trabajador, han sido aceptados como atenuantes o eximentes de la falta cometida ${ }^{65}$.

\section{Aspectos relevantes de la CAUsal}

\section{La gravedad de la conducta injuriosa}

Para que un empleador pueda ocupar la causal del artículo $160 \mathrm{~N}^{\circ} 1$, letra d) CT, referida a las injurias, se precisa la concurrencia de dos requisitos copulativos: (i) La conducta indebida debe estar debidamente comprobada; y (ii) Debe tratarse de una falta grave, vale decir, de mucha entidad, o bien revestir magnitud o significación. La comprobación de los hechos es una exigencia básica de cualquier ordenamiento sancionador, sea cual sea la naturaleza de las infracciones. La extinción, por tanto, no puede encontrarse amparada en la sospecha o la simple posibilidad, pues se trata de hechos que deben tener una fundamentación acabada en la realidad; cuestión que por lo demás es predicable de la totalidad de las causas disciplinarias de despido ${ }^{66}$.

La gravedad, por su parte, deja en evidencia el estándar de relevancia que el legislador le otorga a la aplicación de esta causal. La gravedad es la frontera que permite separar el despido de la mera potestad disciplinaria impositiva de sanciones de menor entidad ${ }^{67}$.

que atenúan esta falta, tales como justos reclamos que no han sido atendidos por el empleador" (sentencia del Tribunal de Alzada de Santiago de 20 de diciembre de 1943, en Repertorio de Legislación y Jurisprudencia Chilenas. Código del Trabajo T. I. Editorial Jurídica de Chile, Santiago 1958, p. 93).

${ }^{63}$ Cfr. sentencia de la Corte de Apelaciones de La Serena de 29 de diciembre de 2003 (Causa Ingreso Corte N N $^{\circ}$ 600-2003: "Que por otra parte, debe tenerse presente que la gravedad de la conducta reprochada se encuentra significativamente atenuada por el hecho de que el trabajador despedido había prestado servicios ininterrumpidos por más de 28 años, sin que exista constancia en autos ni se le haya imputado en ellos un comportamiento anterior censurable, hecho que hace ver también como desproporcionada la medida adoptada".

${ }^{64}$ Cfr., Sánchez-Urán Azaña, Y., y García Piñeiro, N., "Ofensas verbales o físicas al empresario, a las personas que trabajan en la empresa o a sus familiares que convivan con ellos (art. 54.2 c) ET)”. AL No 6 (2005), p. 703.

${ }^{65}$ Cfr. Baylos Grau, "La valoración”, cit., p. 246. Vid. también sentencia de la Corte de Apelaciones de Valdivia de 30 de diciembre de 1994 (Causa Ingreso Corte $N^{\circ}$ 562-1994): “(...) el demandante Miranda no tenía buen genio y (...) en oportunidades contestaba mal, pero estos antecedentes no son suficientes para tener por acreditada la causal de despido invocada por la demandada"; sentencia de la Corte de Apelaciones de Santiago de 31 de agosto de 2011 (Causa Ingreso Corte No 440-2011): “(...) las expresiones vertidas por el trabajador en su cuenta twitter, no tuvieron el ánimo de restar crédito a la empresa o al jefe supuestamente afectado, y faltando este, aunque la crítica sea exagerada o injusta, no puede llegar a conformar la causal de caducidad que se invocó para poner término a su contrato".

66 "Vid. entre otras muchas sentencia de la Corte Suprema de 15 de abril de 1993. RFM No 412 (1993), p. 60; sentencia de la Corte Suprema de 4 de marzo de 1992. GJ N ${ }^{\circ} 141$ (1992), p. 79; sentencia de la Corte Suprema de 11 de septiembre de 1968. RDJ, T. LXV (1968), sección tercera, p. 140; sentencia de la Corte de Apelaciones de Santiago de 25 de enero de 1988. RDJ, T. LXXXV (1988), sección tercera, p. 44; y sentencia de la Corte de Apelaciones de Valparaíso de 15 de junio de 1998. GJ No 233 (1998), p. 157.

${ }^{67}$ Cfr. Cruz Villalón, J., Compendio de Derecho del Trabajo, 2a edición, Tecnos, Madrid 2009, p. 385. 
Por tanto, más que la ocurrencia de situaciones aisladas, sin mayor importancia, o meros incumplimientos ${ }^{68}$, lo que el legislador ha querido sancionar son faltas de una entidad tal que el único camino viable es la extinción del vínculo. ${ }^{69} \mathrm{Y}$ esa calificación, en el caso de las injurias, solo puede verificarse mediante un examen judicial que pondere los aspectos objetivos y subjetivos de la conducta reprochada, teniendo presente los antecedentes y circunstancias que rodean la comisión del hecho.

La regla general en materia de despido disciplinario es que la gravedad no implique, necesariamente, la concurrencia de un dolo específico. Más aún, existen casos en que el propio artículo 160 CT solo exige una falta de diligencia genérica para ciertas causas disciplinarias. Lo que no cabe duda, es que la aplicación de la causa disciplinaria exige una conexión entre la voluntad del trabajador y el hecho que ha dado lugar a la infracción. En otras palabras, las conductas reprochadas "no solo deben ser imputables al trabajador, sino que además deben ser voluntariamente cometidas, por medio de conductas dolosas o meramente negligentes" 70 .

Excepcionalmente, el Código ha circunscrito la causal haciendo referencia a una conducta consciente y dolosa (v. gr., el perjuicio material intencionalmente causado del artículo $160 \mathrm{~N}^{\circ} 6 \mathrm{CT}$ ); o en otras, a una imprudencia temeraria (v. gr., los actos, omisiones o imprudencias temerarias del artículo $\left.160 \mathrm{~N}^{0} 5 \mathrm{CT}\right)^{71}$. En el caso de la injuria, no obstante, y aun cuando se ha pregonado la diferencia entre el ilícito laboral y el de carácter penal, lo cierto es que en la práctica la tendencia jurisprudencial ha sido prácticamente unánime en orden a exigir la concurrencia de un especial ánimo de ofender. Por tanto, no basta la mera voluntariedad; además se requiere una intención específica destinada a provocar los efectos propios de la injuria.

${ }^{68}$ Cfr. Alonso Olea, M., El despido, Instituto de Estudios Políticos, Madrid 1958, pp. 144 y 145.

${ }^{69}$ Cfr. estos criterios en sentencia de la Corte Suprema de 23 de abril de 1998. RDJ, T. XCV (1998), sección tercera, p. 45; y en sentencia de la Corte Suprema de 3 de abril de 1997. RDJ, T. XCIV (1997), sección tercera, p. 35. Vid. también sentencia de la Corte Suprema de 4 de enero de 1990. RDJ, T. LXXXVII, sección tercera (1990), p. 2, la cual concluye que la "reacción verbal del trabajador en contra de su jefe directo, derivada de una extensión indebida de su jornada de trabajo, no reviste la suficiente gravedad para considerarla constitutiva de alguna de las causales de terminación de contrato". Desde luego, la reacción debe ser proporcional a la provocación, ya que en caso contrario la respuesta injuriosa calzará en la hipótesis legal. Ello ocurrió, por ejemplo, en la sentencia dictada por la Corte del Trabajo de Valparaíso de 4 de julio de 1966, citada en Davis, P. R., Terminación del contrato de trabajo, Editorial Bibliográfica Chilena, Santiago s/f, p. 39: “(...) el hecho establecido en el proceso de que la demandante, con motivo de que se le llamara la atención por causas derivadas del trabajo, respondiera a la demandada que 'cuidara más a su marido que tenía una querida en un departamento', constituye en cuanto injuria, causal suficiente y justificada para poner término al contrato de trabajo (...)".

${ }^{70}$ Cfr. Cruz Villalón, cit., p. 385.

${ }^{71}$ La primera de las causales mencionadas (art. $160 \mathrm{~N}^{\mathrm{o}} 6 \mathrm{CT}$ ) no implica necesariamente el reconocimiento previo de un delito. Pero el perjuicio debe ser causado intencionalmente, con un propósito claro de causar daño, sin que sea suficiente la imprudencia o la mera culpa (Vid. sentencia de la Corte Suprema de 12 de marzo de 2008. Causa Ingreso Corte $\mathrm{N}^{\circ}$ 772-2008). En el segundo caso (art. $160 \mathrm{~N}^{\circ} 5$ CT), basta una temeraria falta de diligencia. 
La gravedad de la causal viene a demostrar, asimismo, que los hechos acaecidos son de mucha entidad e importancia, y que su relevancia y magnitud deben ser manifiestas ${ }^{72}$. Dicha gravedad puede estar presente en la falta en sí misma, o bien en sus consecuencias $^{73}$. Y es esa misma relevancia negativa la que obliga a poner término a un contrato que exige de por sí un comportamiento acorde con los principios generales de la buena fe. Lo que ocurre es que los hechos constitutivos de la causal pueden tener una valoración relativa de acuerdo con su entidad, trascendencia o importancia. ${ }^{74} \mathrm{Y}$ ello permite desechar las infracciones aisladas, las expresiones realizadas con justa causa de error, o las faltas mínimas, ya que ellas no están rodeadas de la gravedad suficiente para poder extinguir el contrato de trabajo.

En el caso de la injuria, la gravedad de la falta deja en evidencia también el marco de causalidad que debe rodear al despido. Este sistema de causalidad encuentra su fundamento en un necesario principio de seguridad jurídica, de forma tal que el trabajador tiene la garantía de que solo podrá ser despedido en virtud de una causa expresamente señalada por la ley, más allá de la amplitud que la expresión legal pueda tener ${ }^{75}$. En principio, la gravedad exigida para la injuria debe nacer de hechos más o menos instantáneos que ameritan la extinción inmediata del contrato. Ello no obsta, por cierto, a que la gravedad provenga, también, de una serie de hechos que, "tomados en sí, no son de una gravedad equivalente a la de las causas de género agudo; pero cuya gravedad deriva de la continuidad"76.

De todas formas, cabe tener presente que el calificativo de grave se encuentra estrechamente relacionado con el tipo de contrato de trabajo de que se trate, ya que ciertamente existirán características especiales de cada puesto de trabajo que harán concurrir requisitos singulares para configurar la gravedad ${ }^{77}$. Ello obliga a valorar los grados de imputabilidad, no tanto con criterios absolutos sino que con relación a las características generales del trabajo desempeñado ${ }^{78}$. Lo anterior permite aceptar, al menos en principio, una valoración diversa para un mismo tipo de incumplimiento realizado por distintos trabajadores, "salvo que esta diversa valoración desemboque en un despido discriminatorio"79.

72 Cfr., Sentencia de la Corte de Apelaciones de Valparaíso, de 20 de octubre de 1983. GJ N 40 (1983), p. 113.

${ }^{73}$ Cfr. Gárate Castro, cit., p. 189. Vid. también Rojas Rivero, cit., p. 85

${ }^{74}$ Vid., por todas, sentencias de la Corte Suprema de 14 de diciembre de 1981. RFM N 277 (1981), p. 590; y sentencia de la Corte Suprema de 11 de junio de 1970. RDJ, T. LXVII (1970), sección tercera, p. 51.

${ }^{75}$ Cfr. Montoya Melgar, cit., p. 469.

${ }^{76}$ Cfr. Barassi, L., Tratado de Derecho del Trabajo, T. III, Alfa, Buenos Aires 1953, p. 359.

${ }^{77}$ Cfr. Alonso Olea, cit., p. 147.

78 Cfr. Barassi, T. III, cit., p. 361.

${ }^{79}$ Cfr. Ortiz Lallana, cit., p. 49; y Rojas Rivero, cit., p. 83. Vid. también Aguilera Izquierdo, cit., p. 208: “(...) si el acto ofensivo es colectivo se entiende discriminatorio despedir a uno por todos, pues 'no está ajustado a principios de equidad singularizar y responsabilizar de un acto emanado de un órgano colegiado"”. 
El estándar de gravedad ha derivado en que la jurisprudencia evalúe la conducta infraccional con base en la denominada teoría gradualista y personalizadora. En razón de lo anterior, el juez realizará un examen pormenorizado e individualizado de cada supuesto, "precisando los factores que han concurrido (subjetivos y objetivos), la intención (animus injuriandi), las circunstancias previas, coetáneas y posteriores, la existencia o no de provocación grave" ${ }^{80}$. En síntesis, se exige un análisis individualizado de cada conducta, caso a caso, tomando en consideración las circunstancias que configuran los hechos así como las de su autor ${ }^{81}$.

De esta forma, para que la injuria adquiera la cualidad de causa justificada de extinción resulta imprescindible que la conducta reprochada ostente una relevancia mínima que la separa del mero incumplimiento contractual. Esa relevancia solo podrá ser evaluada judicialmente, analizando de manera pormenorizada el caso en cuestión, el contexto y desarrollo de los hechos, así como las circunstancias objetivas y subjetivas, arribando a calificaciones que han tomado en cuenta el contexto de la injuria, los sujetos intervinientes, y las eventuales atenuantes o agravantes del acto reprochado ${ }^{82}$.

\section{La delimitación entre injuria, derecho al honor y libertad de expresión}

En el ámbito de las relaciones laborales se pone en movimiento un conjunto de derechos y libertades que obligan a delimitar su exacta configuración. Ello ocurre, por ejemplo, cuando se enfrenta el derecho a la libertad de expresión que le corresponde al trabajador con el derecho al honor que ostenta el empleador. En estos casos, lo relevante será determinar cuándo se produce un desborde en el ejercicio de la libertad de expresión incurriendo en un acto injurioso que lesiona el derecho al honor del empleador. Ello es especialmente necesario cuando la libertad de expresión se ejerce por escrito o por un medio de comunicación social, ya que de alguna forma el titular de la libertad ha tenido la posibilidad de sopesar sus acciones así como las consecuencias que se derivan del uso de ciertas palabras ${ }^{83}$.

Como es ampliamente sabido, el artículo $19 \mathrm{~N}^{\circ} 12$ CPR reconoce el derecho a la libertad de emitir opinión y la de informar, sin censura previa, en cualquier forma y por cualquier medio, sin perjuicio de responder de los delitos y abusos que se cometan en el ejercicio de estas libertades. En este contexto, y tal como lo ha reconocido el Tribunal Constitucional, la libertad de expresión desempeña un papel fundamental en la sociedad democrática, pues permite el debate de ideas, el intercambio de puntos de vista, emitir

${ }^{80}$ Vid. García Ninet, cit., p. 199. Vid. también Moreno de Toro, cit., p. 262.

${ }^{81}$ Cfr. Ortiz Lallana, cit., p. 1123. En el plano jurisprudencial Vid. a mayor abundamiento sentencia de la Corte Suprema de 31 de diciembre de 2008. RFM No 550 (2008), p. 375; y sentencia de la Corte Suprema de 1 de julio de 2009 (Causa Ingreso Corte No 2654-2009).

${ }^{82}$ Cfr. Vida Fernández, R., "Ofensas verbales y libertad de expresión en el ámbito de las relaciones laborales”, en Borrajo Dacruz, E. (director), La Ley-Actualidad (1999), p. 412.

${ }^{83}$ Cfr. Aguilera Izquierdo, cit., p. 216. 
y recibir mensajes, la libre crítica, la investigación científica y el debate especulativo, la creación artística, el diálogo sin restricción, censura ni temor, y la existencia de una opinión pública informada. Más aún, dentro de este derecho deben entenderse comprendidas las declaraciones sobre hechos y también las meras opiniones, con independencia de si son fundadas racionalmente o no. La protección de la libertad de expresión alcanza no solo al contenido de las ideas, sino también a la forma en que ellas son expresadas ${ }^{84}$. De esta manera, y centrándonos en la legitimidad del ejercicio de las libertades, habrá que concluir que los hechos siempre serán susceptibles de prueba; las opiniones, en cambio, corresponden más a juicios de valor que no siempre pueden ser sometidos a una demostración de exactitud ${ }^{85}$. Dicho de otra forma, la libertad de expresión goza de un mayor resguardo en comparación con la libertad de información, en razón que esta última debe someterse a una verificación de los hechos externos ${ }^{86}$.

Las consideraciones anteriores, llevadas al ámbito laboral, exigen resolver aquellos casos en que el trabajador ejerce legítimamente su derecho fundamental a la libertad de expresión (desplegando eventualmente su derecho de crítica), de aquellos en que, por el contrario, su actitud rebasa los límites establecidos y se convierte derechamente en un acto injurioso. La problemática anterior debe partir de la base que el trabajador goza, en el ámbito de la relación laboral, de los mismos derechos fundamentales que le corresponden en tanto persona, ya que la celebración del contrato no puede suponer un menoscabo o anulación en el ejercicio de los mismos (aun cuando igual se produce una modalización del derecho en cuestión, contextualizándolo a la dinámica de la realidad laboral).

En este orden de ideas, si bien se reconoce la vigencia del derecho a la libertad de expresión en el contexto de la relación laboral, igualmente habrá que aceptar que este derecho no es ilimitado o absoluto; encontrando límites que afectan tanto al modo de la expresión como a la expresión misma ${ }^{87}$. Desde esta perspectiva, el trabajador cuenta con un derecho genérico para emitir y exteriorizar opiniones, ideas o pensamientos; pero al mismo tiempo, él se encuentra sujeto a determinadas pautas de comportamiento y en caso alguno esta garantía puede amparar una especie de derecho al insulto o al uso de calificativos degradantes ${ }^{88}$; cuestión que ocurrirá cada vez que las expresiones utilizadas dejen en evidencia una finalidad meramente ofensiva.

${ }^{84}$ Vid. sentencia del Tribunal Constitucional de 2 de junio de 2010. Rol No 567-2006.

${ }^{85}$ Cfr. De Vicente Pachés, F., "Despido por denuncias ante los medios de comunicación de anomalías en la empresa relevantes para la opinión pública: el conflicto entre la libertad de información y libertad de empresa". TS N 159 (2004), p. 48.

${ }^{86}$ Cfr. Vida Fernández, cit., p. 407. Vid. también Rojas Rivero, "La libertad”, cit., p. 107, quien matiza esta idea en el sentido de que los hechos o noticias no se dan nunca en un estado químicamente puro "y comprende, casi siempre, algún elemento valorativo (...)".

${ }^{87}$ Cfr., Martínez Rocamora, L. G., "Ofensas verbales y libertad de expresión del trabajador (comentario a la STC 106/1996, de 12 de junio)”, TS No 72 (1996), p. 43.

${ }^{88}$ Cfr. Aguilera Izquierdo, cit., p. 217; y García Ninet, cit., p. 208. 
En rigor, el ejercicio abusivo o desviado de un derecho jamás puede ser aceptado como sinónimo de ejercicio legítimo del mismo. Este planteamiento se ve reforzado por el propio Tribunal Constitucional, cuando señala que el análisis de los derechos debe estar guiado por un principio de unidad de la Constitución, en el entendido que más que observar una norma de forma aislada, ella debe ser configurada dentro del conjunto en el cual se sitúa a objeto de evitar contradicciones. De este modo, "las Constituciones forman un sistema armónico de valores, principios y normas que sirve de fundamento al orden jurídico y social. La idea de la Constitución como un todo orgánico (...) inhibe que se produzcan colisiones entre los preceptos o que algunos queden vacíos de contenido en favor de otros" 89 .

En virtud de lo anterior, el ejercicio de la libertad de expresión y del derecho a crítica por parte del trabajador debe ser armonizado con el derecho al honor y a la propia imagen que tiene el empleador ${ }^{90}$. La libertad que el ordenamiento jurídico le reconoce al trabajador para expresar sus pensamientos, opiniones e ideas, o incluso para ejercer su derecho a crítica, le impide emitir expresiones injuriosas y afectar el honor del empleador. Por cierto, la división es muy delgada en el sentido que pueden existir expresiones molestas o que causen disgustos, pero no necesariamente tendrán que tener el calificativo de injuriosas ${ }^{91}$. Por el contrario, cuando las palabras utilizadas son innecesarias para la expresión de ideas u opiniones, y contienen un alto contenido descalificador, entonces la libertad de expresión tendrá que ceder ante el resguardo del derecho al honor.

Este equilibrio supone reconocer que las libertades que el artículo $19 \mathrm{~N}^{\circ} 12$ CPR le otorga al trabajador no son ilimitadas, y que el ejercicio de esas libertades debe sujetarse a límites que se determinan en función del análisis de las expresiones utilizadas, la finalidad perseguida y los medios en que ella se producen ${ }^{92}$. Desde luego, estos límites en caso alguno pueden ser confundidos con restricciones propias de un régimen de fidelidad que suponga una sumisión total del trabajador a un punto tal que termine anulándose el ejercicio del derecho.

\footnotetext{
${ }^{89}$ Vid. sentencia del Tribunal Constitucional de 2 de junio de 2010. Rol No 567-2006.

90 Cfr. Goñi Sein, "Las ofensas”, cit., p. 471.
}

91 Cfr. Igartúa Miró, cit., p. 93. Como ha señalado el Tribunal Constitucional mediante sentencia de 2 de junio de 2010 ( $R o l N^{\circ}$ 567-2006), las limitaciones a la libertad de expresión no pueden admitirse cuando ellas afectan las ideas, "aunque irriten, alarmen, sorprendan o inquieten a las autoridades". Vid. también sentencia de la Corte Suprema de 27 de enero de 1993. RFM No 410 (1993), p. 1039. En dicha causa, un trabajador fue despedido por su empleador, y varios compañeros de labores solidarizaron con él enviando para tal efecto una carta al gerente de la empresa manifestándole su intención de no participar en las celebraciones del aniversario de la firma. Una de las trabajadoras involucradas en el acto de solidaridad no solo intervino en la confección de la carta sino que, además, dentro de la nómina de los que apoyaban al despedido incluyó - de puño y letra- el nombre de una colega que estaba ausente. Esta conducta fue considerada inaceptable por el empleador, quien procedió a despedir a la trabajadora en cuestión pues se partió de la base que tal comportamiento suponía una falsificación. La Corte rechazó el despido, entre otras razones, porque los "trabajadores hicieron uso de un derecho inalienable, como es la libertad para emitir opinión sobre un despido de un compañero de trabajo”.

${ }^{92}$ Cfr. García Ninet, cit., p. 210. 


\section{Conclusiones}

1. La regulación de la injuria como causal justificada de despido se ha llevado a cabo principalmente por la jurisprudencia, separando los criterios meramente penales de aquellos exigidos en el orden laboral. Desde esta perspectiva, la injuria ha servido para sancionar todas aquellas conductas del trabajador que supongan la ejecución de actos u omisiones que menoscaben la dignidad y el honor del empleador, sin exigir el cumplimiento de requisitos técnicos propios del Derecho penal. En consecuencia, la injuria laboral permite, eventualmente, el encuadre de la causal con el núcleo definitorio de los delitos de injuria o calumnia, pero no se agotan en dichos ámbitos.

2. A partir de la reforma introducida por la Ley $\mathrm{N}^{0} 19.759$ (2001), el núcleo de la infracción se centró en los actos injuriosos cometidos por el trabajador en contra del empleador. Hasta dicha época, la jurisprudencia entendía que la causal también se podía invocar para sancionar otras conductas en que los sujetos pasivos eran los compañeros de labores, las personas que se relacionan con la empresa o incluso los familiares. No obstante, en la actualidad, nada impide que la injuria en contra de personas distintas del empleador (y que se encuentren conectadas con la actividad laboral) puedan ser sancionados por la causal del artículo $160 \mathrm{~N}^{\circ} 7 \mathrm{CT}$; es decir, incumplimiento grave de las obligaciones.

3. El contenido de la injuria laboral es amplio: su aplicación práctica ha supuesto cubrir no solo las expresiones proferidas, sino que, también, gestos, amenazas, ademanes, morisquetas o imitaciones injuriosas que en rigor podrían ser encuadradas en otro tipo de hipótesis extintivas. En el fondo, la jurisprudencia le otorga al término injuria un alcance amplio y omnicomprensivo de cualquier conducta ofensiva o difamatoria del empleador. Ello no impide que la calificación de la injuria se vea afectada por eventuales atenuantes o agravantes, o incluso eximentes así evaluadas por el juzgador.

4. La procedencia de la injuria exige la concurrencia de un especial animus injuriandi, cuestión que ha sido ratificada mayoritariamente por la jurisprudencia y la doctrina. La existencia del animus injuriandi debe ser probado en sede judicial, aun cuando no cabe duda de que existen ciertas expresiones o gestos que son de por sí injuriosos, y que permiten presumir la existencia del animus injuriandi en atención a la gravedad de la conducta.

5. Para que exista injuria laboral, resulta preciso que las expresiones o gestos se ejecuten en un contexto laboral. Por regla general, los actos injuriosos realizados en el lugar de trabajo o durante la jornada gozan de una cierta presunción de laboralidad en razón del contexto. Excepcionalmente, se acepta sancionar aquellas injurias cometidas fuera del lugar o de la jornada, siempre y cuando se encuentren íntimamente vinculadas a la actividad laboral (cuestión que requiere un análisis caso a caso).

6. Para que la injuria adquiera la cualidad de causa justificada de extinción resulta imprescindible que la conducta reprochada ostente una relevancia mínima que la 
separa del mero incumplimiento contractual. Esa relevancia deja en evidencia la gravedad de la falta, y la misma solo podrá ser evaluada judicialmente. Este análisis judicial se lleva a efecto de manera pormenorizada y mediante una evaluación casuística del contexto y del desarrollo de los hechos, así como de las circunstancias objetivas y subjetivas. Ese examen permite concluir si el acto reúne o no las exigencias de gravedad a que se refiere el Código del Trabajo.

7. El trabajador, en tanto titular de derechos fundamentales, tiene derecho al ejercicio de su libertad de expresión. Este ejercicio no es absoluto o ilimitado, debe respetar el derecho ajeno, y en caso alguno puede servir de pretexto para legitimar el uso de palabras injuriosas.

\section{BIBLIOGRAFÍA}

Aguilera IzQuierdo, R., Las causas del despido disciplinario y su valoración por la jurisprudencia. Aranzadi, Pamplona 1997.

Alonso Olea, M., El despido. Instituto de Estudios Políticos, Madrid 1958.

Alonso Olea, M. y Casas Baamonde, M. E., Derecho del Trabajo. Servicio de Publicaciones Facultad de Derecho Universidad Complutense de Madrid, $13^{a}$ edición, Madrid 1994.

Barassi, L., Tratado de Derecho del Trabajo, T. III. Alfa, Buenos Aires 1953.

Baylos Grau, A., "Algunas constantes jurisprudenciales sobre los malos tratos y las faltas graves de respeto como causa de despido”, RPS No 116 (1977).

Baylos Grau, A., "La valoración del comportamiento habitual del trabajador en el despido por malos tratos y faltas graves de respeto", RPS No 119 (1978).

Biblioteca del Congreso Nacional, Historia de la Ley $N^{o} 19.759$ Modifica el Código del Trabajo en lo relativo a las nuevas modalidades de contratación, al derecho de sindicación, a los derechos fundamentales del trabajador y a otras materias que indica.

Cabanellas, G., Tratado de Derecho Laboral, T. II, Vol. 3, Heliasta, $3^{\text {a }}$ edición, Buenos Aires 1988.

Ciscart BeÁ, N., El despido por embriaguez y toxicomanía, Bosch, $1^{a}$ edición, Barcelona 1998.

Cruz Villalón, J., Compendio de Derecho del Trabajo, $2^{a}$ edición, Tecnos, Madrid 2009.

Davis, P. R., Terminación del contrato de trabajo, Editorial Bibliográfica Chilena, Santiago s/f.

De Buen L., N., Derecho del Trabajo, T. II, Porrúa, 9a edición, México DF 1992.

De Vicente Pachés, F., "Despido por denuncias ante los medios de comunicación de anomalías en la empresa relevantes para la opinión pública: el conflicto entre la libertad de información y libertad de empresa", TS No 159 (2004).

Escribar Mandiola, H., Tratado de Derecho del Trabajo, Zig-Zag, Santiago 1944.

Etcheberry, A., Derecho Penal, Editora Nacional Gabriela Mistral, Santiago 1976.

GÁrate Castro, J., "Algunos criterios jurisprudenciales sobre malos tratos a considerar en la aplicación del artículo 52 número 2, c) del Estatuto de los Trabajadores”, RPS No 128 (1980).

García Ninet, J. I., "Ofensas verbales o físicas al empresario o a otras personas del entorno empresarial", en Estudios sobre el despido disciplinario, Acarl, Madrid 1992.

Garrido Montt, M., Derecho Penal, T. III, Editorial Jurídica de Chile, 4ª edición, Santiago 2010.

Gómez Abelleira, F. J., "Las causas disciplinarias del despido", en Antonio V. Sempere Navarro (director), El despido, Aranzadi-Thomson Reuters, $2^{\text {a }}$ edición, Pamplona 2009.

GoÑ I SEIN, J. L., "Las ofensas al honor y la repercusión disciplinaria de las proferidas fuera de la empresa”, RL T. II (1987). 
GoÑ Sein, J. L., El respeto a la esfera privada del trabajador, Civitas, $1^{a}$ edición, Madrid 1988.

Igartúa Miró, M. T., "Ofensas verbales o físicas", en Gorelli Hernández, Juan (coord.), El despido: análisis y aplicación práctica, Tecnos, Madrid 2004.

IrURETA Uriarte, P., "La falta de probidad como causa de extinción del contrato de trabajo", en Libro homenaje al profesor William Thayer Arteaga, Editado por Sociedad Chilena de Derecho del Trabajo y Seguridad Social, Santiago 1998.

Labatut Glena, G., Derecho Penal T. II, Editorial Jurídica de Chile, 7ª edición, Santiago 1996.

Macchiavello Cúneo, G., Derecho del Trabajo T. I, Fondo de Cultura Económica, Santiago 1986.

Martínez Girón, J., El despido en el Derecho de los Estados Unidos, Civitas, 1ª edición 1988.

Martínez Rocamora, L. G., "Ofensas verbales y libertad de expresión del trabajador (comentario a la STC 106/1996, de 12 de junio)", TS No 72 (1996).

Montoya Melgar, A., Derecho del Trabajo. Tecnos, 29a edición, Madrid 2008.

Moreno De Toro, C., "Poder disciplinario, proporcionalidad y discrecionalidad en la imposición de las sanciones", TL N 101 (2009).

Ortiz Lallana, M. C., "Causas y formas del despido disciplinario (en torno a los artículos 54 y 55)", en El Estatuto de los Trabajadores veinte años después. Civitas, $1^{\text {a }}$ edición, Madrid 2000.

Rocha Mora, F., La ley de empleados particulares, Imprenta E. Aracena e Hijo, Santiago 1928.

Rojas Rivero, G. P., La libertad de expresión del trabajador, Tecnos, Madrid 1991.

SaAvedra Acevedo, J., "Los malos tratos y faltas de respeto como causa justa de despido". Dieciséis lecciones sobre causas de despido, Sección de Publicaciones e Intercambio Facultad de Derecho Universidad de Madrid, Madrid 1969.

Sagardoy Bengoechea, J. A., El despido laboral y los expedientes de crisis, Ediciones Deusto, Bilbao 1969.

SÁncheZ-Urán Azaña, Y. y García Piñeiro, N., "Ofensas verbales o físicas al empresario, a las personas que trabajan en la empresa o a sus familiares que convivan con ellos (art. 54.2 c) ET)", AL N ${ }^{\circ} 6$ (2005).

Tapia Carvajal, J., Legislación del Trabajo en Chile. Algunos antecedentes históricos, Memoria de Prueba, Universidad de Chile, Santiago 1937.

Thayer Arteaga, W. y Rodríguez Alvarado, A., Código del Trabajo y Legislación Social, Editorial Jurídica de Chile/Editorial Jurídica Ediar Cono-Sur Ltda., Santiago 1988.

Vida Fernández, R., "Ofensas verbales y libertad de expresión en el ámbito de las relaciones laborales”, en Borrajo Dacruz, Efrén (director), Trabajo y libertades públicas, La Ley-Actualidad (1999).

Walker Errázuriz, F., Derecho de las Relaciones Laborales, Editorial Universitaria, $1^{a}$ edición, Santiago 2003. 
